\title{
Carbon and oxygen stable isotopes of selected Cenomanian and Turonian rudists from Egypt and Czech Republic, and a note on changes in rudist diversity
}

\author{
SOHEIR EL-SHAZLY, MARTIN KOŠŤÁK, GOUdA ABDEL-GAWAD, BLANKA KLOUČKOVÁ, \\ SHABAN GHANEM SABER, YASSER FELIEH SALAMA, MARTIN MAZUCH \& KAREL ŽÁK
}

\begin{abstract}
The stable isotope record and diversity of Cenomanian and Turonian rudists were compared for areas located at low paleolatitudes $\left(10^{\circ} \mathrm{N}\right.$ - Northern Egypt; 5 samples; 13 analyses) and middle paleolatitudes $\left(35^{\circ} \mathrm{N}\right.$ - Czech Republic, Bohemian Cretaceous Basin, BCB; 4 samples; 7 analyses). The oxygen isotope data indicate that the $\delta^{18} \mathrm{O}$ value of seawater was not identical for both areas. Moreover, local variations in seawater $\delta^{18} \mathrm{O}$ in the range of at least $\pm 1 \%$ ore probable in the shallow water near-shore environment where the rudists lived. Supposing a value of $-1 \%$ VSMOW for contemporaneous seawater, the paleotemperature can be calculated as being between 24.5 and $31.5^{\circ} \mathrm{C}$ for the Late Cenomanian and between 32.9 and $34.7^{\circ} \mathrm{C}$ for the Early Turonian in the BCB. The $\delta^{18} \mathrm{O}$ seawater value for the northern part of Egypt was probably slightly lower. Calculation using a seawater value of $-1.5 \%$ VSMOW gives temperatures for the Egypt in the range of 31.0 to $38.8^{\circ} \mathrm{C}$ for the Late Cenomanian and 35.5 to $41.2^{\circ} \mathrm{C}$ for the Turonian. The sclerochronological isotope profiles within one shell show changes of the calcite $\delta^{18} \mathrm{O}$ value, probably reflecting seasonal changes, with the largest observed within-shell temperature shift corresponding to $8{ }^{\circ} \mathrm{C}$. The analyzed pilot sample set shows that the BCB and Egyptian rudists contain valuable paleoenvironmental information and that a detailed isotope study is needed. Rudist generic diversity of both areas was also compared. The Cenomanian and Turonian rudist assemblages from Egypt and the BCB show similar generic diversity, and also display a similar marked diversity decrease across the Cenomanian/Turonian boundary interval. It is important to note that both areas have similar diversity on the generic and partially species level during the Cenomanian and Turonian. - Key words: rudists, Upper Cretaceous, Cenomanian, Turonian, Egypt, Czech Republic, paleoecology, C and O stable isotopes.
\end{abstract}

El-Shazly, S., KoŠŤÁK, M., AbDel-Gawad, G., KloučKová, B., SABer, S.G., FelieH SAlama, Y., MaZuch, M. \& ŽÁK, K. 2011. Carbon and oxygen stable isotopes of selected Cenomanian and Turonian rudists from Egypt and Czech Republic, and a note on changes in rudist diversity. Bulletin of Geosciences 86(2), 209-226 (6 figures, 1 table). Czech Geological Survey, Prague. ISSN 1214-1119. Manuscript received June 1, 2009; accepted in revised form May 20, 2011; published online June 13, 2011; issued June 202011.

Soheir El-Shazly, Gouda Abdel-Gawad, Shaban Ghanem Saber \& Yasser Felieh Salama, Geology Department, Faculty of Science, Beni Suef University, Salah Salem Street 62511, Beni Suef, Egypt; soheir14@gmail.com, g.abdelgawad@bsu.edu.eg, shabansaber@yahoo.com,yfelieh@yahoo.com•Martin Košták (corresponding author) \& Martin Mazuch, Institute of Geology and Palaeontology, Faculty of Science, Charles University, Albertov 6, 12843 Praha 2, Czech Republic; kostak@natur.cuni.cz, mazuch@natur.cuni.cz・Blanka Kloučková, Polabské muzeum in Poděbrady, Palackého 68/III, Poděbrady, Czech Republic; klouckova@pmpodebrady.cz•Karel Žák, Institute of Geology AS CR, v.v.i., Rozvojová 269, 16500 Praha 6, Czech Republic; zak@gli.cas.cz.

The Cretaceous period is generally considered to have been a time of warm climate (e.g., Wilson \& Norris 2001, Norris et al. 2002). Tropical climates between paleolatitudes of $30^{\circ} \mathrm{N}$ and $30^{\circ} \mathrm{S}$ are believed to have contributed to the westward-flowing Tethys Circumglobal Current (TCC) throughout the Cretaceous period (Stanley 1995). Paleogeography, specifically the presence/absence of a marine connection between the North Atlantic and South Atlantic basins, may have governed the nature of the midCretaceous global oceanic circulation (Poulsen et al. 2001). The surface temperature of the warm sea (SST) during that time has been estimated by oxygen isotopic analyses of marine fauna, with a high-latitude SST as high as $16{ }^{\circ} \mathrm{C}$ (Huber et al. 1995) and a low-latitude range of 31 to $33{ }^{\circ} \mathrm{C}$ (Kolodny \& Raab 1988, Wilson \& Norris 2001). SSTs as high as $20{ }^{\circ} \mathrm{C}$ were estimated for the polar sea 


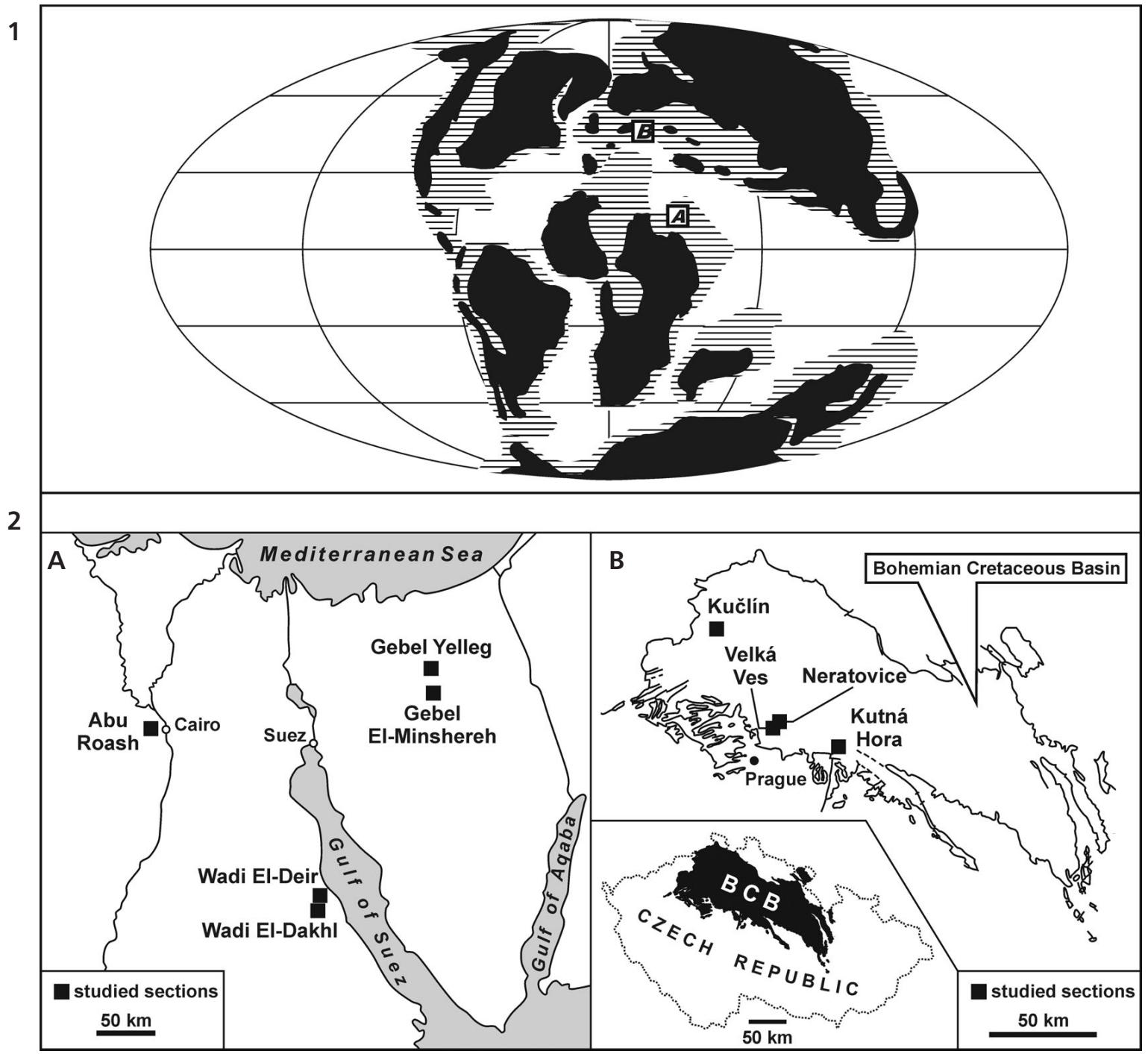

Figure 1. 1 - schematic map of the Cenomanian/Turonian palaeogeography with the position of the studied areas. A - Egypt, B - Czech Republic, Bohemian Cretaceous Basin. Black - continents, hatch - epicontinental seas, white - oceans. $\bullet 2$ - position of localities and areas (see the text) with rudist assemblages studied. A - Egypt, B - Bohemian Cretaceous Basin.

(Arctic-Boreal Realm) by Jenkyns et al. (2004). However, in some periods of short-duration during the Late Cretaceous, limited ice caps and accompanying cooling and shallowing events triggered by glacio-eustasy have also been discussed for the Cenomanian and Turonian ages (e.g., Voigt \& Wiese 2000, Stoll \& Schrag 2000, Borneman et al. 2008, Wiese et al. 2009).

During the Albian-Cenomanian, Upper TuronianConiacian and lower Campanian, a general trend of increasing temperatures is indicated from isotopic excursion of some rudist shells, with the lowest temperatures of 23-25 ${ }^{\circ} \mathrm{C}$ and highest reaching $37{ }^{\circ} \mathrm{C}$, with low intra-annual variation (Steuber et al. 2005).

The Tethys Ocean played a critical role in determining the warm climate and ecosystems of the Cretaceous (Stanley 1995). Westward flow along the circumglobal path
(TCC) may have transported waters throughout the Tethyan region (Stanley 1995), effectively moderating the climate and creating a cosmopolitan tropical biota (Poulsen et al. 1998). However, short-term episodes of cooling have also been reported for the early Late Cretaceous (see above). During the mid-Cretaceous, the rate of ocean crust formation and off-ridge volcanism were greater than at any time since (Arthur et al. 1985). The high rates of seafloor production (Hays \& Pitman 1973) led to sea levels as much as $250 \mathrm{~m}$ higher than present, with fluctuations of $100 \mathrm{~m}$ over $10 \mathrm{Myr}$ (Haq et al. 1987). Additionally, the marked increase in volcanic outgassing contributed to higher atmospheric $\mathrm{CO}_{2}$ concentrations (Arthur et al. 1985). Estimates of $\mathrm{pCO}_{2}$ for the mid-Cretaceous range between 2 and 6 times more than the modern level (Cerling 1991). The maximum sea level highstand during that period was ac- 
companied by enhanced rates of saline deep water formation, higher rates of upwelling, and consequently, increased sea surface fertility and productivity, which led to the deposition of organic carbon-rich facies at the Cenomanian/Turonian boundary (Poulsen et al. 2001).

The average $\delta^{18} \mathrm{O}$ of the seawater $\left(\delta^{18} \mathrm{O}_{\text {sw }}\right)$ of Tethyan Cretaceous ocean is estimated within the range of $-1 \%$ o to $-0.5 \%$ VSMOW at $34 \%$ o salinity (Steuber 1999). Seasonal variations in the $\delta^{18} \mathrm{O}_{\mathrm{sw}}$ can have an effect on the calculated SST (Steuber et al. 2005). Generally, the calculated intra-annual temperature range would increase in case of reduced salinity during the warm season (Steuber et al. 2005). The variation in $\delta^{18} \mathrm{O}_{\mathrm{sw}}$ of surface waters is large in tropical marginal seas and coastal waters because of the influx of freshwater and evaporation of ocean water, especially in restricted environments (Steuber 1999).

The variations in $\delta^{18} \mathrm{O}_{\text {sw }}$ during the mid-Cretaceous Period were discussed by Poulsen et al. (1999). They believed that the mid-Cretaceous $\delta^{18} \mathrm{O}_{\mathrm{sw}}$ varied as a response to variations in precipitation and evaporation, freezing and thawing, and the transport and mixing of seawater by oceanic circulation. They reinterpreted the mid-Cretaceous $\delta^{18} \mathrm{O}_{\mathrm{sw}}$ paleotemperature model, using the Broecker (1989) $\delta^{18} \mathrm{O}_{\mathrm{sw}}$ vs salinity relationship. They also compared it with model-predicted temperature, assuming a $\delta^{18} \mathrm{O}_{\mathrm{sw}}$ value equal to $-1 \%$ V VSMOW, as supported by many authors for the polar-ice free world, and concluded that paleotemperatures in the mid-latitudes varied considerably.

Wefer \& Berger 1991 proposed that extant bivalves are the most faithful records of environmental conditions. They precipitate their calcite or aragonite shells in or near the oxygen isotopic equilibrium with seawater (Killingley \& Berger 1979). This phenomenon has also been demonstrated for Cretaceous bivalves (Steuber 1999). Thus, the rudist bivalves, which were among the most important fauna that evolved during the Cretaceous period, can reasonably be used to indicate palaeotemperature and seasonal variations. Al-Aasm \& Veizer (1986) suggested that their outer shell layer originally consisted of diagenetically stable low Mg calcite and their large size results in well-resolved annual growth increments, which reflect seasonal variations in temperature and/or salinity (Steuber 1999, Steuber et al. 2005). They inhabited tropical and subtropical environments (Ross \& Skelton 1993) and are generally restricted to normal marine environments, though some groups are tolerant to salinity changes (Gili et al. 1995).

The aim of the present work was to compare stable isotope characteristics of rudists from Northern Egypt and the Bohemian Cretaceous Basin in the Czech Republic (Fig. 1), using a pilot sample set. The sclerochronological variability of $\delta^{13} \mathrm{C}$ and $\delta^{18} \mathrm{O}$ values within shell profiles was also analyzed. In addition, rudist diversity on the species and genera levels in the Late Cenomanian-Turonian interval was compared. A marked decrease of rudist-as- semblages diversity was observed for both Egypt and the BCB. That decrease in diversity probably reflects global palaeoceanographic changes during the Cenomanian/Turonian boundary interval and, subsequently, biotic turnover at this boundary, which is characterized by the global occurrence of organic-rich deposits and a carbon isotope excursion (the Cenomanian/Turonian Oceanic Anoxic Event, OAE2 or Bonarelli Event; Hilbrecht et al. 1986, Arthur et al. 1988, Uličný et al. 1993, Kerr 1998, Sagemann et al. 2006, and others).

The Late Cenomanian crises in species richness and abundance in the northern Tethys were coeval with oceanic anoxia associated with platform drowning, characterized by recumbent ecological morphotypes, and predominantly by aragonitic shells (Steuber \& Löser 2000, Steuber 2002). However, the most probable cause of the BCB rudist-assemblage disappearances seems to be a result of the sea-level rise and reduction of natural rudist biotopes that covered the rocky sea-bottom substrate.

\section{Geologic, paleogeographic and stratigraphic settings of the studied rudist-bearing strata}

\section{Cenomanian-Turonian rudist-bearing strata in northern Egypt}

The Late Cretaceous rocks in Egypt show changes ranging from clastic facies in the south, to alternating clastic and non-clastic facies in the central, to carbonate facies in the north. The central and southern parts of Egypt were nearshore marine environments during the Cretaceous, to which rivers from higher areas inputted sediments and water. Consequently, variable salinity and a high influx of terrigenous material characterized this environment. As stenohaline organisms, rudists are rare or absent in southern and central Egypt, but are well developed in platform carbonate in northern Egypt.

Rudist samples were collected from northern Sinai (Gebel El Minshereh and Gebel Yelleg), from the western side of the Gulf of Suez (Wadi El-Deir and Wadi El-Dakhl) and from the Northwestern Desert near the Giza Pyramids in the Abu Roash area (Fig. 1).

The Cenomanian rudists, Eoradiolites liratus (Conard) and Biradiolites zumoffeni Douvillé, were collected from the northern Sinai sections, in the middle part of the Halal Formation of Late Cenomanian age at Gebel Yelleg and Gebel El-Minshereh. These rudist beds are mainly built up of limestone intercalated with marl and dolostone. The rudist fabric and associated microfacies indicate that they were deposited in a low energy inner shelf environment at Gebel El Minsherah (Bauer et al. 2002), to an inner shelf setting or carbonate platform interior, affected by storm 
events at Gebel Yelleg, where they form transgressive system tracts of the sequence 2 (Saber et al. 2009). They are underlain by fossiliferous marly bed with the ammonite Neolobites vibrayeanus d'Orbigny, which indicates a Late Cenomanian age for this horizon (El-Hedeny 2007).

The Tethyan shoreline extended southward to cover the present-day two Galalas areas on the western side of the Gulf of Suez, producing shallow marine deposits of shales and marls with a moderately agitated inner shelf environment (Abd-Elshafy \& Abd El-Azeam 2010).

At Wadi El-Deir and Wadi El-Dakhl, rudists were found in greenish marl overlain by dolomitic limestone and underlain by claystone containing numerous echinoids $\mathrm{He}$ miaster cubicus (Doser) and the ammonite Acanthoceras amphibolum Morrow. Based on the presence of this ammonite, this interval is considered to be of Middle Cenomanian age (Abdel-Gawad et al. 2007).

Rudist shells with the other associated bivalves and Hemiaster cubicus have been recorded from the Cenomanian of Israel and Oman, which indicates communication with the Southern Tethys (Abd-Elshafy \& Abd El-Azeam 2010). This horizon can be correlated to the Rotalipora reicheli Taxon Range Zone of Early to Middle Cenomanian age in Gebel Nazzazat, western side of Gulf of Suez, a Zone that may also be recognized in the boreal and European Mediterranean regions (Shahin 2007).

The Turonian rudist Durania arnaudi (Choffat) was collected from Actaeonella Series (Beadnell 1902) from the El-Hassana section, at Abu Roash (El-Hedenny 2007). The rudists were accumulated as a $4-5 \mathrm{~m}$ thick biostrome associated with the coralline sponge Millestroma nicholsoni Gregory, which is found as isolated mounds or within the rudist biostrome (Abdel Gawad et al. 2001). It is underlain by bioturbated chalky limestone, highly fossiliferous with Trochactaeon salomonis Fraas, and capped by cross-bedded limestone of calcarenite facies. The rudist biostromes recognized in the Actaeonella Series (Late Turonian) were developed with low to moderate energy on deeper parts of subtidal rudist shoals. They form a shallowing-upward sequence indicating that the accommodation space was filled more rapidly than it was created during a highstand stage (Abdel-Gawad et al. 2011).

\section{Cenomanian-Turonian rudist-bearing strata in the Bohemian Cretaceous Basin}

The sediments of the $\mathrm{BCB}$ were deposited in a relatively narrow seaway linking the Boreal Realm in the north with the Tethys shelf in the south (Wiese et al. 2004). The rudist-bearing facies are strongly concentrated into nearshore/shallow water environments. They are typical for the S, SW and NW margin of the BCB.
The sedimentation of Cretaceous deposits in the BCB started in the Early and continued during the Middle Cenomanian as a typical continental depositional sequence (Peruc Beds of the local stratigraphic column; Malkovský et al. 1974; Čech et al. 1980; Uličný et al. 1993, 1997). The basal sediments reflect fluvial freshwater sedimentation with very coarse material deposited by rivers. Generally, towards the overlying strata, fine grained sandstones, siltstones and clayey siltstones are also present. Marine transgression started in the late Middle Cenomanian by sandstones. In addition, the Late Cenomanian organodetritic limestones surround islands and shallow marine slopes, with silts predominant in the deeper basin (Korycany Beds of the local stratigraphic column). The boundary between the Peruc and the Korycany Beds is irregular, with paralic development of several marine incursions into terrestrial areas. During this process, erosion, material transport, and redeposition of sediment were frequent. Therefore, the term Peruc-Korycany Formation is used in the present study to characterize the mixed lithologies deposited in various areas (Houša 1991; Žítt \& Nekvasilová 1996; Žítt et al. 1997a, b, 1998).

Typical rudist biotopes originated in the Late Cenomanian marine environment. They are situated in the near shore/shallow water areas north of the Rhenish-Bohemian Island, predominantly with rocky coast (and rocky sea bottom). It is notable that almost all rudist assemblages recorded are allochtonous, with a damaged apical shell end. They formed larger beach accumulations and accumulative mounds which originated during heavy storms.

In the Kralupy nad Vltavou area (localities Neratovice and Velká Ves, Fig. 1), the sandstones and sandy marls are overlain by biodetritic limestones containing allochtonous rudist fauna (together with corals, cidarid echinoid spines, oysters and pectenid bivalves). During the Cenomanian/Turonian boundary interval (above the Metoicoceras geslinianum ammonite Zone), some elevations and deposits on their slopes were exposed (Svoboda 2006). This is also supported also by the analysis of non-altered rudist shells from Velká Ves, where the possible influence by meteoric water was found (see below). The rudist assemblage consists of the following genera: Araeopleura (Cox), Petalodontia Počta, Simacia Počta, Caprotina (d'Orbigny), Caprina (d'Orbigny), Ichthyosarcolites Desmarest, Plagioptychus Matheron, Radiolites Lamarck and Cryptaulia Počta. This assemblage also has the largest rudist diversity in the BCB (Kloučková 2002).

The Kolín-Kutná Hora area (locality Kutná Hora, Fig. 1) is characterized by an extremely rugged sea bottom relief (Košták et al. 2010). The Neoproterozoic to Early Palaeozoic metamorphic rocks of these Cenomanian islands are composed mostly of paragneisses and migmatites. The area is formed by the Kutná Hora Crystalline Unit in the local geologic terminology. The axial trend 
of Kutná Hora Island, as well as smaller nearby islands, is oriented in a NW-SE direction (Klein 1962; Malkovský et al. 1974; Ziegler 1982, 1992), which is parallel to the axis of the main basin as well. The rudist shell accumulations were preserved in shallow water sediments deposited close to a very irregular shoreline, similar to the Late Cenomanian development (see above). This area is also located between an ancient archipelago (to the north) and the center of the Rhenish-Bohemian Island (to the south). Sediments deposited on the shore of the archipelago are predominantly fine-grained sandstones with larger clasts of quartzite and gneiss, which were washed down from higher elevations of the Kutná Hora Crystalline Unit. Sandstones are intercalated with organodetritic sandy limestones. Klein (1962) supposed these sediments to be a threshold facies (Schwellenfacies) and Houša (1991) interpreted them as fossil beaches with allochtonous material (also including rudists, secondary cidarid echinoids and hexacoral fragments). The contact between the sandstones and limestones is sharp with a typical hardground fabric. These sediments are currently considered to be a tempestite (storm deposit; Fejfar et al. 2005). Biodetrital sandy limestones are composed mainly by the large oyster Rhynchostreon suborbiculatum (Lamarck) and the rudist Radiolites sanctaebarbarae Počta. However, Svoboda (1989) recognized two distinct faunal complexes: Builders of the reef rim just at the sea level - Radiolites sanctaebarbarae Počta, Radiolites humilior (Počta) and oyster Rhynchostreon suborbiculatum (Lamarck), and coral assemblage with Caprotina d'Orbigny and Petalodontia Počta, forming biostroms in shallow water. The rudist assemblage from various sections of the studied area consists of the genera: Araeopleura Cox, Petalodontia Počta, Simacia Počta, Caprotina d'Orbigny, Ichthyosarcolites Desmarest and Radiolites Lamarck. The Late Cenomanian age is determined based on the occurrence of Inoceramus pictus and the rare occurrence of the belemnite Praeactinocamax plenus (Blainville) from the location of Kutná Hora (Košták et al. 2004). The accompanying faunal complex has been described by Kloučková (2002) - Stereocidaris vesiculosa (Goldfuss), Cidaris sorignetti Desor, Exogyra sigmoidea Reuss and shark teeth.

Rudists from the Teplice-Bílina area (locality Kučlín) are of the Early Turonian in age. Fine grained psamitic sediments and organo-detritic limestones indicate a transgressive pulse (Čech \& Váně 1988). A typical rudist fauna consisting of Radiolites bohemicus (Teller), Plagioptychus haueri (Teller) and the oyster Rhynchostreon suborbiculatum (Lamarck) were found. Also, the so-called "Hippuritenschichten" (see Reuss 1844, Krejčí 1869 - actually sediments rich in radiolitid rudists) from Kučlín near Bílina (Fig. 1) are of Early Turonian age. The age is well documented by the inoceramids Mytiloides mytiloides (Mantell) and Mytiloides labiatus (Schlotheim) (Čech \&
Váně 1988). The rudist assemblage from the TepliceBílina area by (Kloučková 2002) consists of Caprotina d'Orbigny, Caprina d'Orbigny, Plagioptychus Matheron and Radiolites Lamarck.

\section{Materials and methods}

The sediments of both studied areas are not metamorphosed and the fossils are well preserved. The Egyptian Cenomanian rudists are represented by Eoradiolites liratus (Conard) and Biradiolites zumoffeni Douvillé, which were collected from north Sinai (Gebel El-Minshereh, and Gebel Yelleg) and the western side of the Gulf of Suez (Wadi El-Deir and Wadi El-Dakhl). The Turonian rudists, which are represented by specimens of Durania arnaudi (Choffat), were collected from Abu Roash area in the Northwestern Desert, near Cairo (Fig. 1). The Bohemian Cretaceous rudists used for the analyses belong to genus Radiolites Lamarck and they are referred to as Radiolites sanctaebarbarae Počta (Cenomanian specimens) and Radiolites undulatus (Geinitz) (Turonian specimen). They come from three localities (see Fig. 1): the SW region of the $B C B$ (Kralupy area - localities Neratovice and Velká Ves), the S (Kolín and Kutná Hora area - locality Kutná Hora) and the NW region of the BCB (Teplice and Bílina area - locality Kučlín). The species identification was performed by the authors.

Nine of the best-preserved samples were selected for isotope analysis. Samples were then cut along the growth axis and the cut surfaces examined by microscope. No detailed chemical or cathodoluminescence analyses of the samples were performed at this pilot research stage, and the samples were studied only by optical methods. Samples for carbon and oxygen isotopic analysis were drilled out from the cut surfaces (see Fig. 2). The original valve wall was studied by microscope, and only well preserved samples showing original structures were selected.

Altogether twenty sub-samples were taken from the shell layers, which contain fibrous prismatic layers. At least two samples were drilled from each shell, except the specimen from Neratovice ( $R$. sanctaebarbarae), where only one sub-sample was obtained. The drilled-spot locations run parallel to the growth axis of the right valve. All samples were analyzed in the Stable Isotope Laboratory of the Czech Geological Survey in Prague, using standard vacuum $\mathrm{H}_{3} \mathrm{PO}_{4}$ digestion followed by measurement of evolved $\mathrm{CO}_{2}$ on a Finnigan MAT 251 mass spectrometer. Overall analytical precision was $\pm 0.1 \%$ o for both $\delta^{13} \mathrm{C}$ and $\delta^{18} \mathrm{O}$. The data are reported relative to the international VPDB standard.

The comparison of the Cenomanian-Turonian rudist diversity in Egypt and the Czech Republic was based on a simple quantitative analysis (Kloučková 2002), based on 
species and genera numbers recorded in the Late Cenomanian and Early Turonian strata (Inoceramus pictus, Calycoceras guerangeri and Metoicoceras geslinianum zones for the Late Cenomanian; Watinoceras devonense, Mammites nodosoides, Mytiloides labiatus Zones for the Early Turonian in the BCB - Košták et al. 2004).

\section{Results of carbon and oxygen stable isotopic analyses}

The Cenomanian rudists in northern Sinai had higher $\delta^{13} \mathrm{C}$ values, with mean values between $2.41 \%$ in Gebel Minshereh and $1.46 \%$ in Gebel Yelleg, but had lower $\delta^{18} \mathrm{O}$ (-5.90\% and $-5.77 \%$ VPDB, respectively). At Wadi El-Dakhl and Wadi El-Dir in southwestern part of the Gulf of Suez, the $\delta^{13} \mathrm{C}$ values are lower and $\delta^{18} \mathrm{O}$ values slightly higher when compared to the northern Sinai (mean $\delta^{13} \mathrm{C}$ values $0.30 \%$ and $0.81 \%$; mean $\delta^{18} \mathrm{O}$ values $-5.72 \%$ and $-5.09 \%$ ). The Turonian species from Abu Roash area shows a mean $\delta^{13} \mathrm{C}$ value of $1.96 \%$ and $\delta^{18} \mathrm{O}$ value of $-6.20 \%$ VPDB.

The Cenomanian shells from the BCB, localities Kutná Hora and Neratovice (Radiolites sanctaebarbarae) have high mean $\delta^{13} \mathrm{C}$ values between $4.30 \%$ and $2.85 \%$, while those from Velká Ves shows a negative $\delta^{13} \mathrm{C}$ value of $-0.54 \%$. The mean $\delta^{18} \mathrm{O}_{\mathrm{cc}}$ values in these areas are negative (Kutná Hora -4.31\%o; Neratovice -2.93\%o; Velká Ves $-6.34 \%$ vs VPDB). The sample from Nová Ves was clearly influenced by either a local near-shore environment with lower $\delta^{18} \mathrm{O}$ and $\delta^{13} \mathrm{C}$ seawater values or by later isotope exchange with meteoric or diagenetic waters (see below).

The Turonian species Radiolites undulatus from Kučlín have a high $\delta^{13} \mathrm{C}$ value of $3.13 \%$ and low $\delta^{18} \mathrm{O}_{\mathrm{cc}}$ value of $-4.84 \%$ o VPDB (see Table 1).

\section{Interpretation and discussion of the results}

\section{Oxygen isotopes}

As is generally known, the $\delta^{18} \mathrm{O}$ values of calcite $\left(\delta^{18} \mathrm{O}_{\mathrm{cc}}\right)$ or aragonite in shells primarily depends on two variables, the $\delta^{18} \mathrm{O}$ of the seawater $\left(\delta^{18} \mathrm{O}_{\mathrm{sw}}\right)$, and the temperature of the environment in which the animal lived. Shells can be precipitated either in a temperature-controlled isotope equilibrium between the seawater and calcite, or under non-equilibrium behavior, related to metabolic kinetic isotope effects. The non-equilibrium behavior usually affects the isotopes of carbon more than the isotopes of oxygen. Rudists are considered to among those animals that precipitate their shells in a temperature-controlled oxygen isotope equilibrium between seawater and calcite (as assumed by e.g., Steuber 1999, Steuber et al. 2005).

The general relationship between $\delta^{18} \mathrm{O}_{\mathrm{sw}}$, temperature, and $\delta^{18} \mathrm{O}_{\mathrm{cc}}$ has been described by several empirical equations (e.g., Epstein et al. 1953, Craig 1965, Anderson \& Arthur 1983). Of these equations, those of Anderson \& Arthur (1983) have become widely used. This equation enables the direct use of a measured $\delta^{18} \mathrm{O}_{\mathrm{cc}}$ value against the VPDB standard and selected $\delta^{18} \mathrm{O}_{\mathrm{sw}}$ value against the VSMOW standard. The older equations contained calcite and water $\delta$-values measured against a working standard gas $\mathrm{CO}_{2}$, and required thus more complex recalculation of the data obtained from the laboratory (given against international VPDB and VSMOW standards). In this paper we use the original version of the equation from Anderson \& Arthur (1983):

$$
\begin{gathered}
\mathrm{T}\left({ }^{\circ} \mathrm{C}\right)=16.0-4.14\left(\delta^{18} \mathrm{O}_{\mathrm{cc}}-\delta^{18} \mathrm{O}_{\mathrm{sw}}\right)+ \\
+0.13\left(\delta^{18} \mathrm{O}_{\mathrm{cc}}-\delta^{18} \mathrm{O}_{\mathrm{sw}}\right)^{2}
\end{gathered}
$$

Where $\delta^{18} \mathrm{O}_{\mathrm{cc}}$ is the $\delta^{18} \mathrm{O}$ value of calcite given against the VPDB standard and $\delta^{18} \mathrm{O}_{\mathrm{sw}}$ is the selected $\delta^{18} \mathrm{O}$ value of the seawater, which in paleo-applications cannot be measured directly, and has to be estimated. Auclair et al. (2003) used a modified version of this equation, which differs in the first constant (16.9 instead of 16.0), thus producing results which are systematically $0.9^{\circ} \mathrm{C}$ higher:

$$
\begin{gathered}
\mathrm{T}\left({ }^{\circ} \mathrm{C}\right)=16.9-4.14\left(\delta^{18} \mathrm{O}_{\mathrm{cc}}-\delta^{18} \mathrm{O}_{\mathrm{sw}}\right)+ \\
+0.13\left(\delta^{18} \mathrm{O}_{\mathrm{cc}}-\delta^{18} \mathrm{O}_{\mathrm{sw}}\right)^{2}
\end{gathered}
$$

The average $\delta^{18} \mathrm{O}$ of the seawater $\left(\delta^{18} \mathrm{O}_{\mathrm{sw}}\right)$ of the Tethyan Cretaceous ocean is estimated to range from $-1.0 \%$ to $-0.5 \%$ o VSMOW at $34 \%$ o salinity (Steuber 1999). Under present-day conditions the seawater $\delta^{18} \mathrm{O}_{\mathrm{sw}}$ value and salinity are interrelated, and can be described by an equation of Buening \& Spero (1996):

$$
\delta^{18} \mathrm{O}_{\mathrm{sw}}=0.39 * \text { salinity }-13.46
$$

where the $\delta^{18} \mathrm{O}_{\mathrm{sw}}$ value is in \%o against VSMOW and salinity is given in $\%$ of salts. The relationships between these variables in individual periods of the geological past can be slightly different, especially in the constant of the equation. Using the estimate of Steuber (1999) for the

Figure 2. A - Radiolites sanctaebarbarae Počta, Upper Cenomanian, Kutná Hora, Czech Republic. • B - Radiolites sanctaebarbarae Počta, Upper Cenomanian, Neratovice, Czech Republic. $\bullet \mathrm{C}-$ Radiolites sanctaebarbarae Počta, Upper Cenomanian, Velká Ves, Czech Republic. $\bullet$ D - Radiolites undulatus (Geinitz), Lower Turonian, Kučlín, Czech Republic. • E - Eoradiolites liratus (Conard), Upper Cenomanian, Gebel El-Minshereh, Egypt. - F - Durania arnaudi (Choffat), Lower Turonian, Abu Roash, Egypt. • G - Eoradiolites liratus (Conard), Upper Cenomanian, Wadi El-Dakhl, Egypt. - H - Biradiolites zumoffeni Douvillé, Upper Cenomanian, Gebel Yelleg, Egypt. • I - Eoradiolites liratus (Conard), Upper Cenomanian, Wadi El-Deir, Egypt. $• \mathrm{~J}-$ Praeradiolites sinaiticus Douvillé, complete specimen, Upper Cenomanian, Gebel Yelleg, Egypt. The scale bar is $1 \mathrm{~cm}$. 
Soheir El-Shazly et al. • Carbon and oxygen stable isotopes of selected Cenomanian and Turonian rudists
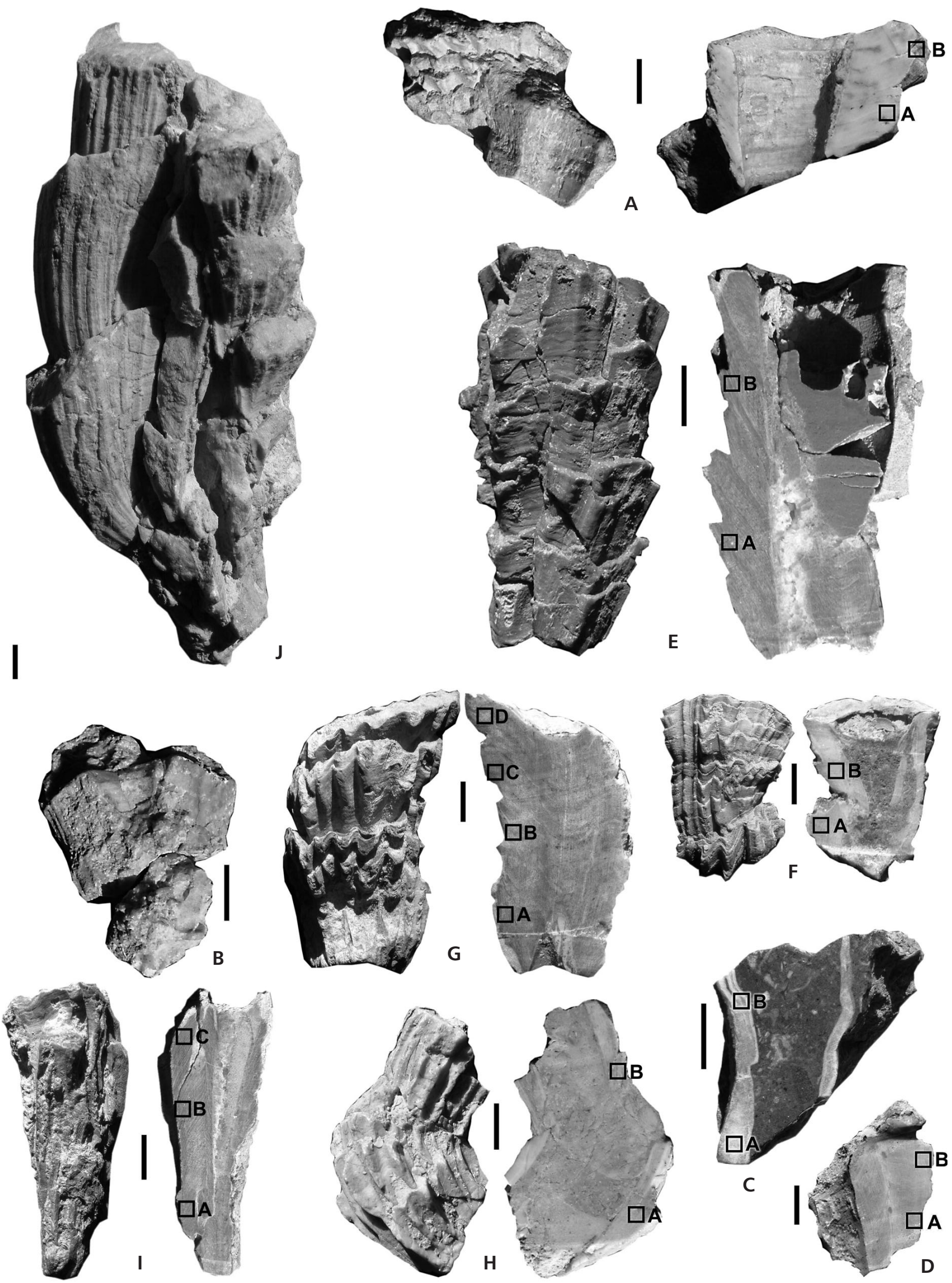
Table 1. Table of the $\mathrm{C}$ and $\mathrm{O}$ isotope data obtained from Cenomanian and Turonian rudist shells. The temperatures are calculates for $\delta^{18} \mathrm{O}_{\text {sw }}$ values of $-0.5,-1.0,-1.5$, and $-2.0 \%$ VSMOW using the equation of Anderson \& Arthur (1983). The temperatures used in the interpretation are shown in grey.

\begin{tabular}{|c|c|c|c|c|c|c|c|c|}
\hline \multirow[t]{2}{*}{ Locality } & \multirow[t]{2}{*}{ Species } & \multirow{2}{*}{ Subsample } & \multirow{2}{*}{$\begin{array}{c}\delta^{13} \mathrm{C} \\
(\% o, \mathrm{VPDB})\end{array}$} & \multirow{2}{*}{$\begin{array}{c}\delta^{18} \mathrm{O} \\
(\% o, \mathrm{VPDB})\end{array}$} & \multicolumn{4}{|c|}{ Temperature calculated for $\delta^{18} \mathrm{O}_{\mathrm{sw}}$ value of } \\
\hline & & & & & $-0.5 \%$ & $-1.0 \%$ & $-1.5 \%$ & $-2.0 \%$ \\
\hline Kutná Hora, Czech Republic & Radiolites sanctaebarbarae & $1 \mathrm{~A}$ & 4.08 & -4.38 & 34.0 & 31.5 & 29.0 & 26.6 \\
\hline \multirow[t]{2}{*}{ Cenomanian } & & $1 \mathrm{~B}$ & 4.52 & -4.24 & 33.3 & 30.8 & 28.3 & 25.9 \\
\hline & & mean & 4.30 & -4.31 & 33.7 & 31.1 & 28.7 & 26.3 \\
\hline Neratovice, Czech Republic & Radiolites sanctaebarbarae & 2 & 2.85 & -2.93 & 26.8 & 24.5 & 22.2 & 20.0 \\
\hline \multicolumn{9}{|l|}{ Cenomanian } \\
\hline Velká Ves, Czech Republic & Radiolites sanctaebarbarae & $3 \mathrm{~A}$ & -0.46 & -6.07 & 43.1 & 40.3 & 37.6 & 35.0 \\
\hline \multirow[t]{2}{*}{ Cenomanian } & & $3 \mathrm{~B}$ & -0.61 & -6.61 & 46.1 & 43.3 & 40.5 & 37.8 \\
\hline & & mean & -0.54 & -6.34 & 44.6 & 41.8 & 39.1 & 36.4 \\
\hline Gebel El-Minshereh, Egypt & Eoradiolites liratus & $5 \mathrm{~A}$ & 2.35 & -6.23 & 44.0 & 41.2 & 38.5 & 35.8 \\
\hline \multirow[t]{2}{*}{ Cenomanian } & & $5 \mathrm{~B}$ & 2.46 & -5.57 & 40.3 & 37.6 & 35.0 & 32.4 \\
\hline & & mean & 2.41 & -5.90 & 42.1 & 39.4 & 36.7 & 34.1 \\
\hline Wadi El-Dakhl, Egypt & Eoradiolites liratus & $7 \mathrm{~A}$ & 0.10 & -5.97 & 42.5 & 39.8 & 37.1 & 34.5 \\
\hline \multirow[t]{4}{*}{ Cenomanian } & & $7 \mathrm{~B}$ & 0.23 & -5.85 & 41.9 & 39.1 & 36.5 & 33.9 \\
\hline & & $7 \mathrm{C}$ & 0.95 & -4.78 & 36.1 & 33.5 & 31.0 & 28.5 \\
\hline & & $7 \mathrm{D}$ & -0.08 & -6.29 & 44.3 & 41.5 & 38.8 & 36.2 \\
\hline & & mean & 0.30 & -5.72 & 41.2 & 38.5 & 35.8 & 33.2 \\
\hline Gebel Yelleg, Egypt & Biradiolites zumoffeni & $8 \mathrm{~A}$ & 1.47 & -5.76 & 41.4 & 38.7 & 36.0 & 33.4 \\
\hline \multirow[t]{2}{*}{ Cenomanian } & & $8 \mathrm{~B}$ & 1.45 & -5.78 & 41.5 & 38.8 & 36.1 & 33.5 \\
\hline & & mean & 1.46 & -5.77 & 41.4 & 38.7 & 36.0 & 33.5 \\
\hline Wadi El-Deir, Egypt & Eoradiolites liratus & $9 \mathrm{~A}$ & 0.76 & -4.90 & 36.7 & 34.1 & 31.6 & 29.1 \\
\hline \multirow[t]{3}{*}{ Cenomanian } & & $9 \mathrm{~B}$ & 0.77 & -5.21 & 38.4 & 35.7 & 33.1 & 30.6 \\
\hline & & $9 \mathrm{C}$ & 0.89 & -5.16 & 38.1 & 35.5 & 32.9 & 30.4 \\
\hline & & mean & 0.81 & -5.09 & 37.7 & 35.1 & 32.5 & 30.0 \\
\hline Kučlín, Czech Republic & Radiolites undulatus & $4 \mathrm{~A}$ & 3.19 & -5.01 & 37.3 & 34.7 & 32.1 & 29.6 \\
\hline \multirow[t]{2}{*}{ Turonian } & & $4 \mathrm{~B}$ & 3.06 & -4.67 & 35.5 & 32.9 & 30.4 & 28.0 \\
\hline & & mean & 3.13 & -4.84 & 36.4 & 33.8 & 31.3 & 28.8 \\
\hline Abu Roash, Egypt & Durania arnaudi & $6 \mathrm{~A}$ & 2.05 & -5.67 & 40.9 & 38.2 & 35.5 & 32.9 \\
\hline \multirow[t]{2}{*}{ Turonian } & & $6 \mathrm{~B}$ & 1.87 & -6.73 & 46.8 & 44.0 & 41.2 & 38.5 \\
\hline & & mean & 1.96 & -6.20 & 43.8 & 41.0 & 38.3 & 35.7 \\
\hline
\end{tabular}

Tethyan Cretaceous seawater, that is an average $\delta^{18} \mathrm{O}_{\text {sw }}$ value of $-0.75 \%$ o VSMOW at $34 \%$ o salinity, the following data can be estimated: $\delta^{18} \mathrm{O}_{\mathrm{sw}}$ of $-0.5 \%$ VSMOW at a salinity of $34.6 \%$ o, $\delta^{18} \mathrm{O}_{\mathrm{sw}}$ of $-1.0 \%$ VSMOW at a salinity of $33.4 \%$, and $\delta^{18} \mathrm{O}_{\mathrm{sw}}$ of $-1.5 \%$ VSMOW at a salinity of $32 \%$.

Rudists are generally considered to be stenohaline animals, usually living in a salinity range of 32 to $36 \%$ o (Steuber 1999). They are commonly found together with stenohaline coral, echinoid and inoceramid assemblages; however, they are also known from restricted lagoons (Schafhauser et al. 2003) which likely had higher salinity.

Calculated hypothetical temperatures of formation for all studied samples are given in Table 1 using the four different $\delta^{18} \mathrm{O}_{\mathrm{sw}}$ values of $-0.5,-1.0,-1.5$ and $-2.0 \%$ o VSMOW, which is a range covering practically all reason- able $\delta^{18} \mathrm{O}_{\text {sw }}$ values. The temperatures calculated for rudists from Egypt and the BCB are too high when using a $\delta^{18} \mathrm{O}_{\text {sw }}$ of $-0.5 \%$ VSMOW, mostly exceeding $35{ }^{\circ} \mathrm{C}$. Published estimates of the $\delta^{18} \mathrm{O}_{\mathrm{sw}}$ values for the mid-Cretaceous suggest steep latitudinal changes. Using the diagram of Poulsen et al. (1999) and Cretaceous paleolatitudes of both studied areas, a $\delta^{18} \mathrm{O}_{\mathrm{sw}}$ value of $-1.5 \%$ for Egypt, and a value of $-1.0 \%$ VSMOW for BCB were selected as the most appropriate $\delta^{18} \mathrm{O}_{\text {sw }}$ estimates (Fig. 3).

When compared to other BCB samples, the BCB sample from Velká Ves shows significantly lower $\delta^{13} \mathrm{C}_{\mathrm{cc}}$ and $\delta^{18} \mathrm{O}_{\mathrm{cc}}$ values, thus yielding an unrealistically high calculated temperature. Either the formation of this rudist shell was influenced by locally higher influence of the meteoric water in the near-shore environment ( $c f$. Sakai \& Kano 2001), or its original isotope record was modified during 
diagenesis. This sample was therefore excluded from further interpretation. When excluding this sample, the calculated temperature ranges in Egypt $\left(\delta^{18} \mathrm{O}_{\mathrm{sw}}\right.$ of $-1.5 \%$ o VSMOW) range from 31.0 to $38.8{ }^{\circ} \mathrm{C}$ for the Late Cenomanian, and 35.5 to $41.2{ }^{\circ} \mathrm{C}$ in the Early Turonian, while in the Czech Republic, BCB $\left(\delta^{18} \mathrm{O}_{\mathrm{sw}}\right.$ of $-1.0 \%$ o VSMOW) yielded temperatures in the range 24.5 to $31.5{ }^{\circ} \mathrm{C}$ for the Late Cenomanian, and 32.9 to $34.7^{\circ} \mathrm{C}$ for the Early Turonian (Fig. 4).

Similar high temperatures were indicated from isotopic excursions of some rudist shells from the Albian-Cenomanian, Upper Turonian-Coniacian and Lower Campanian, with temperatures up to $37{ }^{\circ} \mathrm{C}$ and low intra-annual variation with minimum temperatures of $23-25^{\circ} \mathrm{C}$ (Steuber et al. 2005). Also, high temperatures generally exceeding $30{ }^{\circ} \mathrm{C}$ were calculated for the mid-Cretaceous oceans in northwest Africa, the eastern equatorial Indian Ocean and the tropical and subtropical regions (Poulsen et al. 1999).

A comparison of the environmental settings of the studied rudists from both localities may provide some indications of salinity variations. Although the estimated average $\delta^{18} \mathrm{O}_{\text {sw }}$ of the Tethyan Cretaceous ocean water is within the range of $-1 \%$ o to $-0.5 \%$ VSMOW at $34 \%$ o salinity (Steuber $1999)$, seasonal variations in $\delta^{18} \mathrm{O}_{\mathrm{sw}}$ could have a larger effect on the calculated SSTs. Generally, the intra-annual temperature range would increase with reduced salinity during the warm season (Steuber et al. 2005). The variation in the $\delta^{18} \mathrm{O}$ of surface waters is large in tropical marginal seas and coastal waters, due to the influx of freshwater and evaporation of ocean water especially in restricted environments (Steuber 1999). The rudists from the northern Egypt probably lived in a quite restricted subtidal lagoonal habitat, which may have been affected by fresh water influx causing $\delta^{18} \mathrm{O}_{\mathrm{sw}}$ depletion. The $\mathrm{BCB}$ rudists (except the Velká Ves sample) lived on the seaward slope of an offshore bank, and were probably less affected by seasonal salinity changes. The shells indicate a probable open-ocean $\delta^{18} \mathrm{O}_{\text {sw }}$ value of $-1 \%$, a value that has generally been assumed for an ice-free Cretaceous (Shackleton \& Kennett 1975).

\section{Carbon isotopes}

Interpretation of the carbon isotope data and recalculation to the $\delta^{13} \mathrm{C}$ value of marine bicarbonate is complicated by the fact that biological kinetic isotope fractionation, or the incorporation of carbon from sources other than wellmixed seawater bicarbonate, can affect the $\delta^{13} \mathrm{C}_{\mathrm{cc}}$ values. In addition, metabolic factors as well as changes in other variables can have an effect on the final shell $\delta^{13} \mathrm{C}$ values. The rates of carbon sedimentation may also reflect an increase in atmospheric $\mathrm{CO}_{2}$ levels, temperature and humidity changes, weathering rates, runoff sedimentation rates, as well as

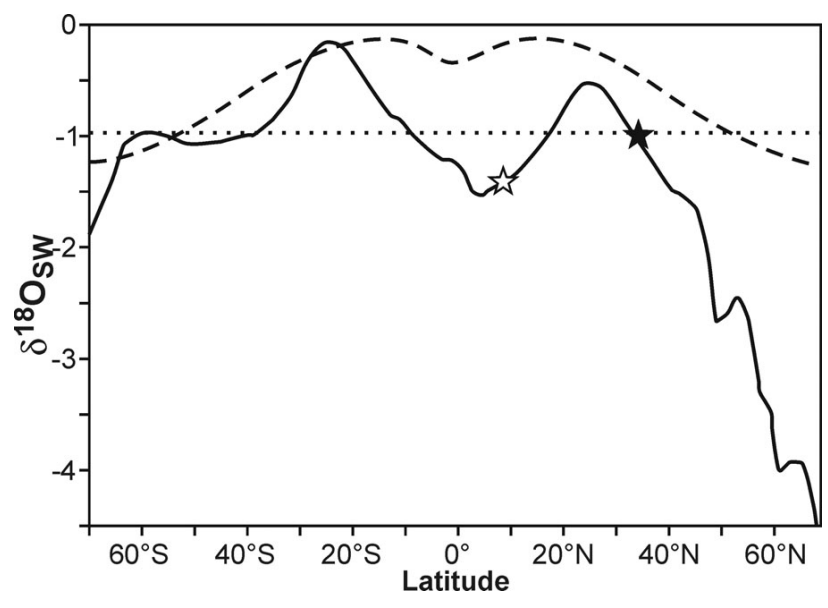

Figure 3. Latitudinal changes in average $\delta^{18} \mathrm{O}_{\mathrm{sw}}$ values after Poulsen et al. (1999), with the position of the studied areas. The dashed line represents the Zachos et al. (1994) curve that best fits the modern distribution of $\delta^{18} \mathrm{O}_{\mathrm{sw}}$ in the South Pacific and South Atlantic Oceans between $70^{\circ} \mathrm{S}$ and $0^{\circ}$. The solid line represents the mid-Cretaceous model $\delta^{18} \mathrm{O}$ value, which was constructed by Poulsen et al. (1999), by applying the Broecker (1989) $\delta^{18} \mathrm{O}_{\mathrm{sw}}$-salinity relationship to the model-predicted zonally averaged mixed-layer salinity. The empty star represents the position of Egyptian rudist samples and the full star represents the Bohemian rudists.

an increase of oceanic nutrients and marine productivity (Weissert \& Lini 1991). An increase in continental vegetation during the warm Cretaceous period would have concentrated ${ }^{13} \mathrm{C}$ in the atmosphere at the same time, affecting the ${ }^{13} \mathrm{C} /{ }^{12} \mathrm{C}$ ratio of the oceans (Renard 1986).

The peculiar morphological shape of some rudists indicates exposure of their mantle tissue to sunlight, which has been explained as an indirect adaptation to phytosymbiosis. Photosymbiosis can result in lowering of the $\delta^{13} \mathrm{C}$ data (Skelton \& Wright 1987, Kauffman \& Johnson 1988). Similar depletions were recorded from some Late Cretaceous rudists from Greece and Turkey by Steuber (1995). Shifts of the shell $\delta^{13} C_{c c}$ values relative to equilibrium with sea-water dissolved bicarbonate may be caused by the utilization of metabolic $\mathrm{CO}_{2}$ during shell formation (Grossman 1987), photosynthetic activity of symbionts, growth rate, and variation in carbonate ion concentration (Spero \& Lea 1996).

The lower $\delta^{13} \mathrm{C}$ value (Table 1) of the shell from Wadi El-Dakhl $\left(\delta^{13} \mathrm{C}\right.$ values range from $-0.08 \%$ o to $0.95 \%$ ) may be related to the boring activities of algae. El-Hedeny \& El-Sabbagh (2005) recorded such boring features from the Saint Paul area, where the parautochthonous rudist E. $l i$ ratus is affected by dense algal borings. They interpreted these borings as being formed from a pre-death to a prebiostratinomic phase. Such a symbiosis with green algae may modify the isotopic composition of the skeletal carbonate in most marine organisms (Erez 1978). Symbiotic Zooxanthellae are commonly associated with corals and modify $\delta^{13} \mathrm{C}$ either via respiration rate (McConnaughey et 


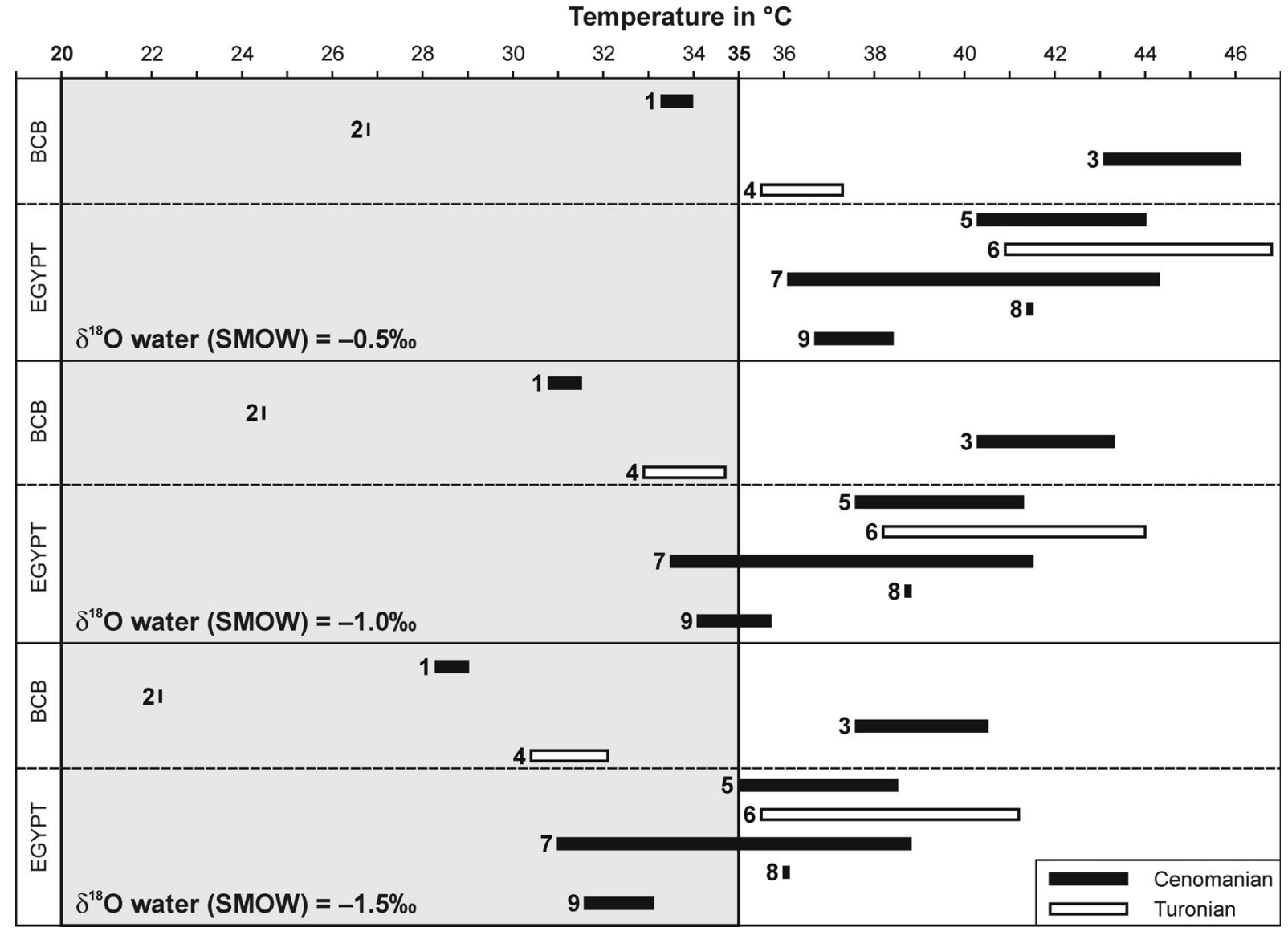

Figure 4. The calculated paleotemperature ranges of the studied rudist shells using different $\delta^{18} \mathrm{O}_{\text {sw }}$ assumptions. The grey area represents the range of Cretaceous water temperature after Steuber et al. (2005). The numbers are identical to sample numbers in Table 1 and Fig. 5.

al. 1997), or photosynthetic activity (Swart 1983, McConnaughey 1989). Juillet-Leclerc \& Reynaud (2010) believed that $\delta^{18} \mathrm{O}$ and $\delta^{13} \mathrm{C}$ values of corals are affected by both light and the abundance of symbiotic Zooxanthellae, confusing the isotopic behaviors of $\delta^{18} \mathrm{O}$ and $\delta^{13} \mathrm{C}$. Fortunately, only the $\delta^{13} \mathrm{C}_{\mathrm{cc}}$ values of rudist shells can be affected by this process, while $\delta^{18} \mathrm{O}_{\mathrm{cc}}$ values are considered to be formed in equilibrium with seawater. There have been debates about the effect of photosynthesis on the $\delta^{13} \mathrm{C}$ value in the skeletal carbonate. While Swart et al. (1996) believe that there is an inverse correlation between $\delta^{13} \mathrm{C}$ and photosynthesis/respiration ratio, Erez (1978) proposed an alternative hypothesis which suggests that an increased rate of photosynthesis causes the isotopically depleted values.

The Late Cenomanian sediments at north Sinai represent the sequence post Ce Sin 6 of Bauer et al. (2003), which is correlated to sequence 2 , dated between $~ 93.7$ to $\sim 93.45 \mathrm{Ma}$ (Saber et al. 2009) at Gebel El-Minshereh. The average $\delta^{13} \mathrm{C}$ values of Eoradiolites lariatus during that age had positive average carbon values of $2.41 \%$ and $1.46 \%$ VPDB at Gebel El-Minshereh and Gebel Yelleg, respectively. The rudists had lower $\delta^{13} \mathrm{C}$ values in the Early-Middle Cenomanian sediments at Wadi El-Dakhl and Wadi El-Deir, with averages of $0.30 \%$ and $0.81 \%$ o VPDB, respectively. These changes in the $\delta^{13} \mathrm{C}$ values from Egyptian rudists are most probably related to a sea level increase during the Cenomanian. The relationship between the carbon isotope profiles and eustatic sea-level changes is remarkably consistent in the Cenomanian and Campanian. The increasing $\delta^{13} \mathrm{C}$ accompanies a sea-level rise, while the decreasing $\delta^{13} \mathrm{C}$ accompanies a sea-level fall (Mabrouk et al. 2007).

Figure 5. Sclerochronological profiles with intra-shell variations of isotopic values. 1-4 - rudist shells from Czech Republic: 1 - Kutná Hora, 2 - Neratovice, 3 - Velká Ves, 4 - Kučlín. 5-9 - rudist shells from Egypt: 5 - Gebel El-Minshereh, 6 - Abu Raoash, 7 - Wadi El-Dakhl, 8 - Gebel Yelleg, 9 - Wadi El-Deir. The relevant data (more than two samples from one shell) were obtained from sclerochronological profiles with intra-shell variations of isotopic values in Eoradulites liratus from Wadi El-Dakhl and Wadi El-Deir. The temperatures shown are calculated supposing a $\delta^{18} \mathrm{O}_{\text {sw }}$ value of -1.0\%o VSMOW for the BCB and $-1.5 \%$ for Egypt. 
Soheir El-Shazly et al. • Carbon and oxygen stable isotopes of selected Cenomanian and Turonian rudists

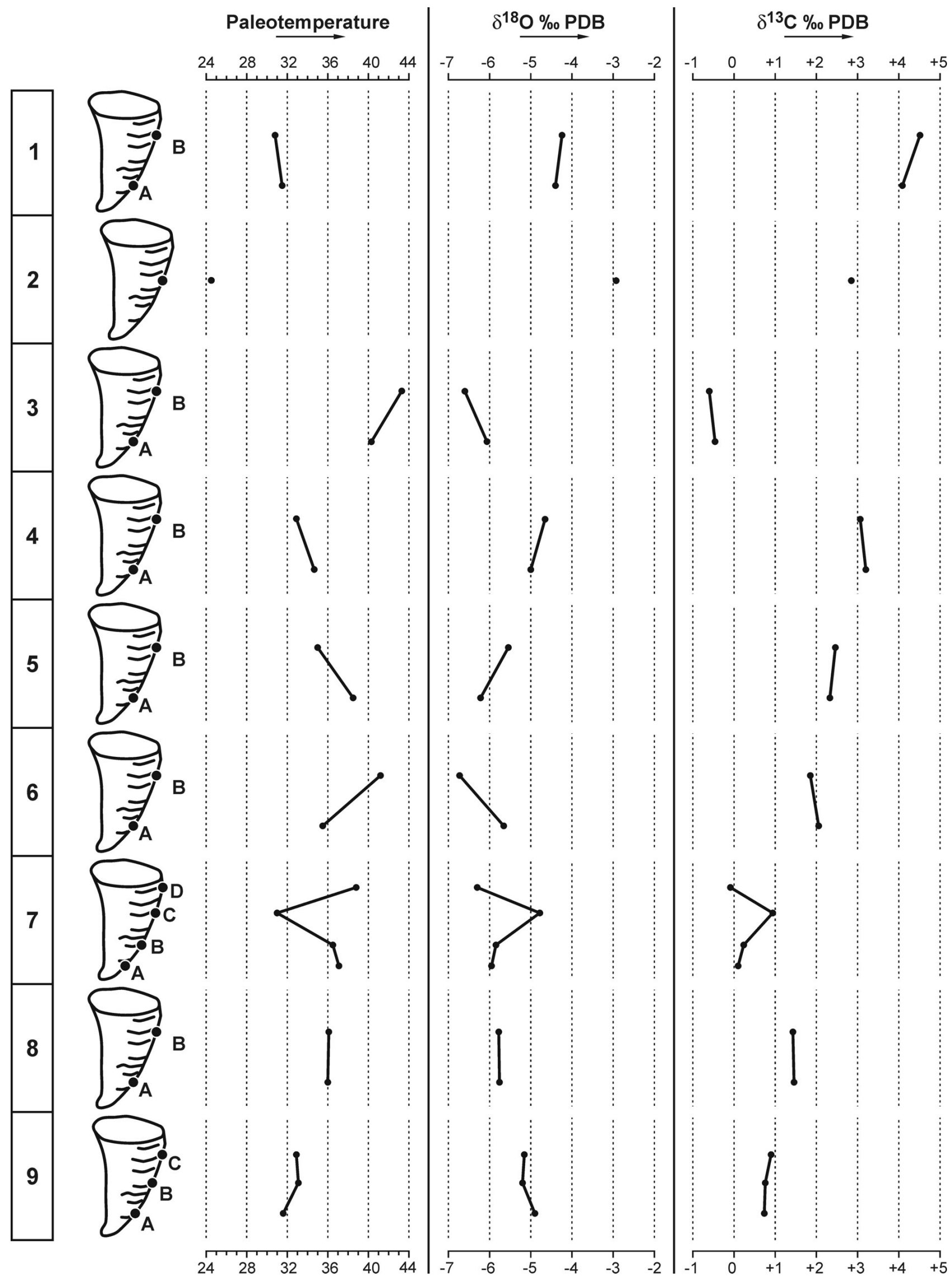


The carbon isotopes may also be interpreted as an indicator of shell formation paleodepth, because shallow water bicarbonate is richer in ${ }^{13} \mathrm{C}$ than is deep water (Duplessy 1972). In corals, the average $\delta^{13} \mathrm{C}$ of similar species is lower for deeper living corals than those growing at shallower depths (Swart et al. 1996). In the present study, the studied rudist samples from the shallower environment at Gebel El-Minsherah show higher $\delta^{13} \mathrm{C}$ values than those from Gebel Yelleg. On the other hand, the northern Sinai shells agree with the carbon isotopic data for the Middle to Late Cenomanian planktonic and benthic foraminifera from DSDP site 463 (Pacific Ocean), which range between $2.00 \%$ and $1.72 \%$ in R. cushmani (Price \& Hart 2002). They also agree with the carbon isotopic composition in the Upper Cenomanian foraminifera of the eastern Alps, Upper Austria, where the values oscillate slightly around the value of 2.5\%o (Wagreich et al. 2008).

The $\delta^{13} \mathrm{C}$ values of the Cenomanian rudists show similarity to the $\delta^{13} \mathrm{C}$ results recorded from the Late Cretaceous radiolitid rudists of Central Greece, where the $\delta^{13} \mathrm{C}$ ranged between $0.8 \%$ and $2.2 \%$ (Steuber 1996). Only the shell from Wadi El-Dakhl shows a lower average $\delta^{13} \mathrm{C}$ value $(0.3 \%$ ).

Moreover, the $\delta^{13} \mathrm{C}$ of the shell from Wadi El-Deir (average $\delta^{13} \mathrm{C}$ of $0.81 \%$ ) agrees with the Middle Cenomanian bulk sample at Gebel Nazzazat on the eastern side of the Gulf of Suez showing $\sim 0.88 \%$ during the top of the foraminiferal Rotalipora reicheli zone (Shahin 2007).

The Turonian was a period of marked eustatic change and tectonic activity along the southern Tethyan margin, accompanied by the gradual drop of the sea-level in north Egypt and Sinai (Kuss 1992). The Turonian rudists Duronia arnaudi from Abu Roash were collected from the Actaeonella series of Beadnell (1902), and associated with Actaeonella salomonis, Nerinea requieniana. This succession can be correlated to the Late Turonian, Wata Formation in Sinai and the western side of the Gulf of Suez.

Compared to the Turonian rudists in north Sinai, we find that the rudists re-colonized in the carbonate shelf during the transgressive system tract of sequence 4 in Tu Sin2 between 92.10 and $91.93 \mathrm{Ma}$ (Saber et al. 2009). The shell indicates enrichment in $\delta^{13} \mathrm{C}$ values $\sim 2 \%$ which agrees also with the increase in $\delta^{13} \mathrm{C}$ values recorded from Gebel Nazzazat during the Late Turonian, with an excursion of $1.60 \%$ indicating a relatively shallow depth (Shahin 2007).

In the BCB, the marked basin deepening occurred in the Early Turonian. This is connected to gradual Turonian warming, which culminated in the Middle Turonian but then interrupted by a cooling event in the Upper Turonian (Wiese \& Voigt 2002, Wiese et al. 2004, Košták \& Wiese 2011). However, another cooling event (the Plenus event) connected to shallowing has also recently been discussed for the Late Cenomanian in Europe, as indicated by a glacio-eustatic sea-level fall (Wiese et al. 2009).
The $\delta^{13} \mathrm{C}$ values of the shell from the $\mathrm{BCB}$ range between $-0.46 \%$ to $4.52 \%$ in the Radiolites sanctaebarae. The lower $\delta^{13} \mathrm{C}$ value of the shell at Velká Ves can be explained by extremely shallow water conditions and the probable influx of meteoric water. The positive $\delta^{13} \mathrm{C}$ values in specimens from Kutná Hora and the Turonian locality of Kučlín (Radiolites undulatus) indicate a shallower water environment (rudists are shallow water organisms with photosymbionts in their tissue).

\section{Intra-shell isotope variations}

Sclerochronological profiles along the dorsal and anterior side of the lower valve of Eoradiolites liriatus (Conard) are drawn to show the $\delta^{18} \mathrm{O}$ and $\delta^{13} \mathrm{C}$ variations (Fig. 5). These variations are obvious in the shell collected from Wadi El-Dakhl, where 4 sub-samples were analyzed. The $\delta^{13} \mathrm{C}$ value gradually increases from $0.10 \%$ o to $0.95 \%$, followed by a decrease to $-0.08 \%$ VPDB towards the youngest part of the shell. The $\delta^{18} \mathrm{O}$ changes run roughly parallel to the $\delta^{13} \mathrm{C}$ curve, and show a relative increase in oxygen (from $-5.97 \%$ o to $-4.78 \%$ ) followed by negative shift down to $-6.29 \%$ VPDB. When interpreting the $\delta^{18} \mathrm{O}$ record as a result of temperature changes only, the observed trend would correspond to a temperature decrease of about $6{ }^{\circ} \mathrm{C}$ followed by an abrupt increase of almost $8^{\circ} \mathrm{C}$ (Fig. 5). The observed differences are probably related to seasonal changes. More detailed sampling is needed to elucidate these changes in detail.

\section{Remarks to the Cenomanian-Turonian rudist diversity in the $B C B$ and Egypt}

The rudist diversity was evaluated on both the generic and species levels, with quantitative analysis providing interesting data (Fig. 6). Nine genera are recognized in the Cenomanian through the Early Turonian interval in the mid-latitudes (i.e. BCB) (genera are listed in order of increasing species number, $c f$. Fig. 6): Caprina (d'Orbigny), Simacia (Počta), Ichthyosarcolites (Desmarest), Plagioptychus (Matheron), Cryptaulia (Počta), Araeopleura (Cox), Radiolites (Lamarck), Petalodontia (Počta), and Caprotina (d'Orbigny). The highest diversity has been observed in Caprotina (8 species), Petalodontia (6 species) and Radiolites (5 species). The number of the Late Cenomanian species reaches 29, while only 7 species were recorded from the Early Turonian (Kloučková 2002). This very high diversity seems to be related to the location of the BCB at the periphery of the rudist geographic distribution. The European platform seas with various biotopes may thus be considered a place conducive to allopatric speciation. 
Soheir El-Shazly et al. • Carbon and oxygen stable isotopes of selected Cenomanian and Turonian rudists
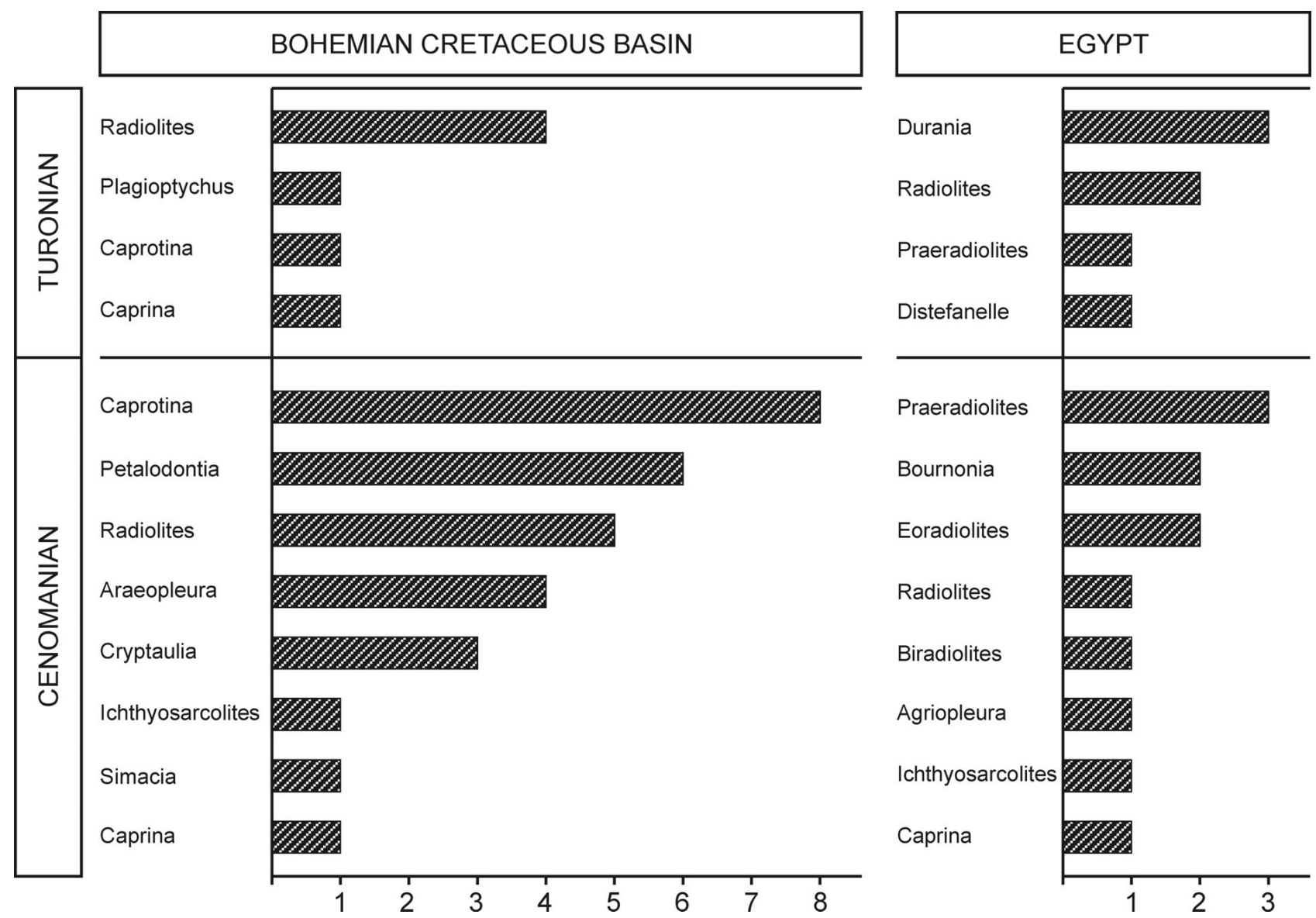

Figure 6. The Cenomanian/Turonian rudist diversity at the generic and species levels in the BCB and Egypt. The horizontal axis shows number of species.

Late Cenomanian species (I. pictus/M. geslinianum zones) recorded in the BCB are as follows: Genus Radiolites: R. bohemicus (Teller), R. sanctaebarbarae Počta, $R$ saxoniae (Roemer), R. undulatus (Geinitz), R. humilior Počta. Genus Caprotina: C. semistriata d'Orbigny, $C$. accuminata Počta, C. deformis Počta, C. perplexa Počta, C. sinuata Počta, C. sodalist Počta, C. stimulus Počta, C. vadosa Počta. Genus Caprina: $C$. striata Počta. Genus Ichthyosarcolites: I. ensis Počta. Genus Araeopleura: A. angustissima (Počta), A. carinoperculata (Počta), A. pileus (Počta), A. venusta (Počta). Genus Petalodontia: $P$. aculeodentata Počta, $P$. crassodentata Počta, $P$. foliodentata Počta, P. germari (Geinitz). P. opima Počta, $P$. planoperculata Počta. Genus Simaica: $S$. minima Počta. Genus Cryptaulia: C. paradoxa Počta, C. perlonga Počta, C. triangulum Počta.

Turonian species (M. labiatus/M. nodosoides zones) recorded in the BCB are as follows: Genus Radiolites: $R$. bohemicus (Teller), R. sanctaebarbarae Počta, $R$. saxoniae (Roemer), R. undulatus (Geinitz). Genus Caprotina: C. semistriata d'Orbigny. Genus Caprina: C. laminea Geinitz. Genus Plagioptychus: P. haueri (Teller) (Kloučková 2002).
Rudist assemblages from Egypt show similar diversity on the generic level (10), but with markedly fewer species (19). There are 8 genera known from the Cenomanian sediments and 4 from the Middle and the Late Turonian.

Late Cenomanian species recorded in Egypt are as follows: Eoradiolites liratus (Conard), Praeradioites biskraensis (Conquand), Praeradiolites sinaiticus Douvillé, Praeradiolites cf. irregularis Douvillé, Bournonia fourtaui Douvillé, Biradiolites zumoffeni Douvillé, Durania humei Douvillé, Ichthyosarcolites triangularis Desmarest, Caprinula sp.

Turonian species recognized are recorded in Egypt are as follows: Praeradiolites ponsianus aegyptiaca Douvillé, Bournonia fourtaui Douvillé, B. excavata d'Orbigny, race roachensis Douvillé, Durania gaensis (Dacqué) and Durania arnaudi (Choffat) (El-Hedenny 2007).

In contrast to the rudists from the higher Bohemian (mid) latitudes, the Egyptian specimens are generally larger in shell size. Shell size among in species individuals from the BCB varies from 13-27 mm in Simacia, from 22-42 $\mathrm{mm}$ in Caprotina and from 20-93 mm in Radiolites (Kloučková 2002). These smaller sizes are comparable in specimens of all species collected from different areas in 
the $\mathrm{BCB}$, thus indicating similar paleoecological conditions (i.e. depth, salinity, temperature, nutrient input etc.) in the rudist biotopes in the $\mathrm{BCB}$.

The decrease in rudist diversity at the Cenomanian/Turonian boundary interval is marked (Jones \& Nicol 1986, Steuber \& Löser 2000). The drop in diversity of more than $55 \%$ genera and $70 \%$ of the species in the BCB shows indicates large palaeoecologic changes across the Cenomanian/Turonian boundary interval. Only one new genus and one new species occurred in the Early Turonian in the BCB. The sea level rise in the Early Lower Turonian and sea deepening resulted in the disappearance of natural rudist biotopes in Central Europe. The decrease and the disappearance of shallow water carbonate platforms in the northern Tethys strongly influenced the Central European region including the BCB (as a gateway to the Tethys; Wiese et al. 2004). The discontinuance of migration pathways for larvae probably decreased diversity. Tethyan rudist buildups in the north only occurred again in the Late Turonian of southern France (Voigt 1996) and Pyreneans (Spain; Pons \& Sirna 1992). Also, the OAE2 (Oceanic Anoxic Event 2) likely affected larger rudist populations during the terminal Cenomanian and at the Cenomanian/Turonian boundary interval. It is notable that no dominant bioherms builder rudists such as those found in the south (Adriatic plate, Middle East, north Africa) were present in the BCB, but rather only parts of biostromes in association with oysters, and rarely corals and stromatopors.

In the Middle East, the Late Cenomanian/Turonian Anoxic Event (OAE2) also influenced the species richness and rudist abundance. Besides the decrease in the abundance of genera and species, the event was also associated with a change in shell shapes and different rudist morphotypes. The platform drowning associated with the Turonian is characterized by the largely calcitic elevator morphotypes Radiolitidae and Hippuritidae, which replaced the aragonitic recumbent rudist morphotypes (Caprinidae, Ichthyosarcolitidae) that dominated during the Cenomanian (Steuber \& Löser 2000).

\section{Conclusions}

From the study of carbon and oxygen stable isotopic composition of the rudist shells from Egypt (Cretaceous paleolatitute of $10^{\circ} \mathrm{N}$ ) and the Bohemian Cretaceous Basin (BCB) in the Czech Republic (Cretaceous paleolatitude of $35^{\circ} \mathrm{N}$ ) during the Cenomanian and Turonian ages, it can be concluded that:

1. This pilot study confirms previous estimates that the $\delta^{18} \mathrm{O}_{\text {sw }}$ value of the Tethyan Ocean was not identical in both areas, with lower $\delta^{18} \mathrm{O}_{\mathrm{sw}}$ in the southern region.

2. For the $\mathrm{BCB}$ area (using a $\delta^{18} \mathrm{O}_{\mathrm{sw}}$ value of $-1.0 \%$ o VSMOW) the calculated temperatures range from 24.5 and $31.5^{\circ} \mathrm{C}$ in the Late Cenomanian, and from 32.9 and 34.7 in the Early Turonian.

3. The sample from BCB, locality Velká Ves, was excluded from the temperature calculation. Either this specimen was formed in near the shore in an extremely shallow environment, influenced by meteoric water influx, or was diagenetically modified.

4. For the Egyptian area (using a $\delta^{18} \mathrm{O}_{\mathrm{sw}}$ value of $-1.5 \%$ o VSMOW) the calculated temperatures range from 31.0 to $38.8^{\circ} \mathrm{C}$ for the Late Cenomanian, and from 35.5 to $41.2^{\circ} \mathrm{C}$ in the Turonian. If the $\delta^{18} \mathrm{O}_{\mathrm{sw}}$ value was lower, the real temperatures SST may also have been lower. The calculation using a $\delta^{18} \mathrm{O}_{\mathrm{sw}}$ value of -2.0\% VSMOW produces temperature data in a more realistic range, which may indicate the influx of freshwater.

5. The lower $\delta^{13} \mathrm{C}$ values of the shell from Wadi El-Dakhl may be related to algal boring activities and photosymbiotic organisms.

6. The rudist assemblages from Egypt and the BCB during the Cenomanian and Turonian age show a marked diversity decrease across the Cenomanian/Turonian boundary (OAE2) interval.

7. This extinction event (and faunal change) selectively affected families which originated during the Early Cretaceous. Subsequently, the family Radiolitidae, which has elevator morphotypes and thick outer shell layers of calcite, started to dominate in the BCB.

8. In Egypt, the Cenomanian-Turonian extinction was restricted to groups which had a recumbent or clinging life habit (Caprinidae, Ichthyosarcolitidae), while Caprinidae are represented by only one species in the $\mathrm{BCB}$. In the $\mathrm{BCB}$, Monopleuridae went extinct at the Cenomanian/Turoninan boundary interval and Caprotinidae was significantly reduced. The extinction at this boundary affected more than $55 \%$ of genera and $70 \%$ of species in the BCB.

9. In the Turonian, a single caprotinid species appeared in the BCB, while Durania species dominated in Egypt.

\section{Acknowledgements}

The research was financed by the project GACR 205/07/1365 and further supported by research programs MSM0021620855 and AV0Z30130516. We also thank referees Klaus Bandel, Oliver Lehnert, and one anonymous reviewer for critical comments and manuscript corrections.

\section{References}

Abdel-Gawad, G.I., El-Sheikh, H.A, Abdelhamid, M.A., El-Beshtawy, M.K, Abed, M.M., Fürsich, F.T \& El-Qot, G.M. 2001. Stratigraphic studies on some the Upper Cretaceous successions in Sinai, Egypt. Egyptian Journal of Paleontology 4, 263-303. 
Abdel-Gawad, G.I., El-Qot, G. \& Mekawy, M.S.M.E. 2007. Macrobiostratigraphy of the Upper Cretaceous succession from Southern Galala, Eastern Desert, Egypt, 329-349. In Youssef El-SAYed, A.A. (ed.) Proceedings of the $2^{\text {nd }}$ International Conference on the Geology of Tethys, Cairo University 2.

Abdel-Gawad, G.I., Saber, S.G., El-Shazly, S.H. \& Felieh, Y. 2011. Turonian rudists from Abu-Roash area, north-western Desert, Egypt. Journal of African Earth Sciences, in press. DOI 10.1016/j.jafrearsci.2011.01.008

Abd-Elshafy, E. \& Abd El-Azeam, S. 2010. Paleogeographic relation of the Egyptian Northern Galala with the Tethys during the Cretaceous Period. Cretaceous Research 31(3), 291-303. DOI 10.1016/j.cretres.2009.11.003

AdABI, M.H. \& RoA, C.P. 1991. Petrographic and Geochemical evidence for original carbonate (Mozduram Formation) Sarakhs area, Iran. Sedimentary Geology 72, 253-267. DOI 10.1016/0037-0738(91)90014-5

Al-Asam, I. \& VeIzer, J. 1986. Diagenetic stabilization of aragonite and low Mg-calcite II. Stable isotope in rudists. Journal of Sedimentary Petrology 56, 763-770.

Andreson, T.F. \& Arthur, M.A. 1983. Stable isotope of oxygen and carbon and their application to sedimentologic and paleoenvironmental problems. Society of economic paleontologists and mineralogists, Short Course 10,1-151.

Arthur, M.A., Dean, W.E. \& Schlanger, S.O. 1985. Variation in the global carbon cycle during the Cretaceous related to climate volcanism, and changes in the atmospheric $\mathrm{CO}_{2}$. Geophysical Monographs 32, 504-529.

Arthur, M.A., Dean, W.E. \& Pratt, L.M. 1988. Geochemical and climatic effects of increased marine organic-carbon burial at the Cenomanian-Turonian boundary. Nature 335, 714-717. DOI 10.1038/335714a0

Auclair, A.-C., Joachimski, M.M. \& Lécuzer, C. 2003. Deciphering kinetic, metabolic and environmental controls on stable isotope fractionations between seawater and the shell of Terrebratalia transversa (Brachiopod). Chemical Geology 202, 59-78. DOI 10.1016/S0009-2541(03)00233-X

Bauer, J., Kuss, J. \& Steuber, T. 2002. Platform environments, microfacies and system tracts of the Upper CenomanianLower Santonian of Sinai, Egypt. Facies 47, 1-26. DOI 10.1007/BF02667703

Bauer, J., Kuss, J. \& Steuber, T. 2003. Sequence architecture and platform configuration (Late Cenomanian-Santonian), Sinai, Egypt. Sedimentology 50, 387-414. DOI 10.1046/j.1365-3091.2003.00549.x

Beadnell, H.J.L. 1902. The Cretaceous region of Abu Roash nears the Pyramids of Giza. 48 pp. Geological Survey Report, Part II, Geological Survey Department, Egypt.

Bornemann, A., Norris, R.D., Friedrich, O., Beckmann, B., Schouten, S., Damsté, J. S., Vogel, J., Hofmann, P. \& WaGNER, T. 2008. Isotopic evidence for glaciation during the Cretaceous supergreenhouse. Science 319(5860), 189-192. DOI 10.1126/science.1148777

Brocker, W.S. 1989. The salinity contrast between the Atlantic and Pacific Oceans during glacial time. Paleoceanography 4, 207-212. DOI 10.1029/PA004i002p00207

Buening, N. \& Spero, H.J. 1996. Oxygen- and carbon-isotope analyses of the articulate brachiopod Laquesus californians: A recorded of environmental changes in the subeuphotic zone. Marine Biology 127(1), 105-114. DOI 10.1007/BF00993650

ČECH, S. \& VÁNĚ, M. 1988. K otázkám vývoje cenomanu a spodního turonu v Podkrušnohoří. Časopis pro mineralogii a geologii 33(4), 395-410.

ČECH, S., KLein, V., KŘİ̌z, J. \& VALEČKA, J. 1980. Revision of the Upper Cretaceous stratigraphy of the Bohemian Cretaceous Basin. Věstník Ústředního ústavu geologického 55(5), 277-298.

Cerling, T.E. 1991. Carbon dioxide in the atmosphere: Evidence from Cenozoic and Mesozoic paleosols. American Journal of Science 291, 377-400. DOI 10.2475/ajs.291.4.377

Craig, H. 1965. The measurement of oxygen isotope paleotemperature, 161-182. In TongioRgi, E. (ed.) Stable Isotopes in Oceanographic Studies and Paleotemperature. Spoleto: Consiglio Nazionale delle Ricerche Laboratorio di Geologica Nucleare, Pisa.

Deines, P., Langmuir, D. \& Harmon, R.S. 1974. Stable Carbon isotope ratios and the existence of a gas phase in the evolution of carbonate ground waters. Geochimica et Cosmochimica Acta 38(7), 1147-1164. DOI 10.1016/0016-7037(74)90010-6

DuPLESSY, J.C. 1972. La Geochimie des isotopes du carbone dans la mer. 196 pp. Ph.D. thesis, Paris University.

El-Hedeny, M.M. 2007. New taxonomic and biostratigraphic data on the Upper Cenomanian Turonian Radiolitidae (Bivalvia: Hippuritoidea) of Abu Roash, Western Desert, Egypt. Neues Jahrbuch für Geologie und Palaontologie 244(1), 79-98.

El-Hedeny, M.M. \& El-Sabbagh, A.M. 2005. Eoradiolites liratus (Bivalvia, Radiolitidae) from the Upper Cenomanian Galala Formation at Saint Paul, Eastern Desert (Egypt). Cretaceous Research 26(4), 551-566.

DOI 10.1016/j.cretres.2005.02.005

Epstein, S., Buchsbaum, R., Lowenstam, H.A. \& Urey, H.C. 1953. Revised carbonate-water isotopic temperature scale. Geological Society of America Bulletin 64, 1315-1326. DOI 10.1130/0016-7606(1953)64[1315:RCITS]2.0.CO;2

EREZ, J. 1978. Vital effect on stable-isotopic composition seen in foraminifera and coral skeletons. Nature 273, 1999-2002. DOI 10.1038/273199a0

FeJfar, O., KošŤÁk, M., KvačEK, J., Mazuch, M. \& MoučKa, M. 2005. First Cenomanian dinosaur from Central Europe (Czech Republic). Acta Palaeontologica Polonica 50(2), 295-300.

Gili, E., MAsse, J.-P. \& Skelton, P.W. 1995. Rudist as gregarious sediment-dwellers, not reef-builders, on the Cretaceous carbonate platforms. Palaeogeography, Palaeoclimatology, $\mathrm{Pa}$ laeoecology 118(3-4), 245-267. DOI 10.1016/0031-0182(95)00006-X

Grossman, E.L. 1987. Stable isotope in modern benthonic foraminifera: a study of vital effect. Journal of Foraminiferal Research 17(1), 48-61. DOI 10.2113/gsjfr.17.1.48

Haq, B., Hardenbol, J. \& Vail, P.R. 1987. Chronology of the fluctuating sea levels since the Triassic. Science 235, 1156-1167. DOI 10.1126/science.235.4793.1156

Hays, J.D. \& PitMan III, W.C. 1973. Lithospheric plate motion, sea level changes and climatic and ecologic consequences. Nature 246(5427), 18-22. DOI 10.1038/246018a0

Hilbrecht, H., Arthur, M.A. \& Schlanger, S.O. 1986. The Cenomanian-Turonian boundary event: sedimentary, faunal 
and geochemical criteria developed from stratigraphic studies in NW-Germany. Lecture Notes in Earth Sciences 8, 345-351. DOI 10.1007/BFb0010217

HoušA, V. 1991. Faciální členění příbřežních mořských sedimentů české křídy. Časopis Národního muzea, Řada př́rodovědná 156(1987), 101-115.

Huber, B.T., Hodell, D.A. \& Hamilton, C.P. 1995. Middle-Late Cretaceous climate of the southern high latitudes: Stable isotopic evidence for minimal equator-to-pole thermal gradients. Geological Society of America Bulletin 107, 1164-1191. DOI 10.1130/0016-7606(1995)107<1164:MLCCOT>2.3.CO;2

Jenkyns, H.C., Foster, A., Schoulten, S. \& Sinninghe Damsté, J.S. 2004. High temperatures in the Late Cretaceous Arctic Ocean. Nature 432, 888-892. DOI 10.1038/nature03143

JoNES, D.S. \& Nicol, D. 1986. Origination, survivorship, and extinction of rudist taxa. Journal of Paleontology 60(1), $107-115$.

Juillet-Leclerc, A. \& Reynaud, S. 2010. Light effects on the isotopic fractionation of skeletal oxygen and carbon in the cultured zooxanthellate coral, Acropora: implications for coralgrowth rates. Biogeosciences 7, 893-906. DOI 10.5194/bg-7-893-2010

KaufFMAn, E.G. \& Johnson, C.C. 1988. The morphlogical and ecological evolution of Upper Cretaceous reef-building rudists. Palaios 3, 194-216. DOI 10.2307/3514530

KERR, A.C. 1998. Oceanic plateau formation: a cause of mass extinction and black shale deposition around the Cenomanian-Turonian boundary? Journal of Geological Society London 155, 619-626. DOI 10.1144/gsjgs.155.4.0619

KiLlingley, J.S. \& Berger, W.H. 1979. Stable isotope in mollusk shell: Detection of upwelling events. Science 205, 186-188. DOI 10.1126/science.205.4402.186

KLEIN, V. 1962. Litologie a stratigrafie cenomanských organodetritických vápenců v západním okolí Kutné Hory. Sborník Ústředního ústavu geologického, Oddíl geologický 27(1960), 385-399.

KLOUČKOVÁ, B. 2002. Rudisti české křídové pánve. 93 pp. Master thesis, Faculty of Science, Charles University, Prague.

Kolodny, Y. \& RAAB, M. 1988. Oxygen isotopes in phosphatic fish remains from Israel: Paleothermometry of tropical Cretaceous and Tertiary shelf waters. Palaeogeography, Palaeoclimatology, Palaeoecology 64, 59-67. DOI 10.1016/0031-0182(88)90142-3

KošŤÁk, M., Čech, S., Ekrt, B., Mazuch, M., Wiese, F., Voigt, S. \& Wood, C.J. 2004. Belemnites of the Bohemian Cretaceous Basin in a global context. Acta Geologica Polonica 54(4), 511-533.

KoŠŤÁK, M., VodrÁŽKA, R., FrAnK, J., MAZUCh, M. \& MAREK, J. 2010. Late Cretaceous nautilid beaks from the near shore/shallow water deposits of the Bohemian Cretacaeous Basin (Czech Republic). Acta Geologica Polonica 60(3), 417-428.

KošŤÁk, M. \& WIESE, F. 2011. Extremely rare Turonian belemnites from the Bohemian Cretaceous Basin and their palaeogeographical importance. Acta Palaeontologica Polonica 56(2), 433-437. DOI 10.4202/app.2010.0004

KREJČí, J. 1869. Allgemeine und orographische Verhältnisse sowie Gliederung der böhmischen Kreide-Formation. Archiv pro přirodovědecký výzkum Čech I, 39-179.

Kuss, J. 1992. The Aptian-Paleocene shelf carbonate of Northeast
Egypt and southern Jordon: Establishment and break-up of carbonate platforms along the southern Tethyan shore. Zeitschrift der deutschen geologischen Gesellschaft 143, 107-132.

Mabrouk, A., Jarvis, I., Belayouni, H., Moody, R.T.J. \& SandMAN, R. 2007. Sequence stratigraphy, sea level change \& paleoenvironments via chemostratigraphy: regional to global correlations. Abstracts of AAPG Annual Convention, Long Beach, California, 2007.

http://www.searchanddiscovery.net/abstracts/html/2007/annual/ index.htm

Malkovský, M., Benešová, Z., Čadek, J., Holub, V., ChaloupSkÝ, J., Jetel, J., Müller, V., Mašín, J. \& TÁsler, R. 1974. Geologie české kř́lové pánve a jejího podloži. 262 pp. Ústřední ústav geologický v Nakladatelství Československé akademie věd, Praha.

McConnaughey, T.A. 1989. ${ }^{13} \mathrm{C}$ and ${ }^{18} \mathrm{O}$ isotopic disequilibrium in the biological carbonates: II. In vitro simulation of kinetic isotope effect. Geochimica et Cosmochimica Acta 53, 163-171. DOI 10.1016/0016-7037(89)90283-4

McConnaughey, T.A., Burdett, J., Whelan, J.F. \& Paull, C.K. 1997. Respiration and photosynthesis: Effects on the carbon-13 content of biological carbonates. Geochimica et Cosmochimica Acta 61, 611-622.

DOI 10.1016/S0016-7037(96)00361-4

Norris, R.D., Bice, K.L., MAngo, E.A. \& Wilson, P.A. 2002. Jiggling the tropical thermostat in the Cretaceous hothouse. Geology 30, 299-302. DOI 10.1130/0091-7613(2002)030<0299:JTTTIT>2.0.CO;2

PoČTA, F. 1889. O rudistech, vymřelé čeledi mlžů z českého křídového útvaru. Rozpravy Královské české společnosti nauk 7(3), 1-92.

Pons, J.M. \& SiRnA, G. 1992. Upper Cretaceous rudist distribution in the Mediterranean Tethys: comparison between platforms from Spain and south central Italy. Geologica Romana 28, 341-349.

Poulsen, C.J., Barron, E.J., Arthur, M.A. \& Peterson, W.H. 2001. Response of the mid-Cretaceous global oceanic circulation to tectonic and $\mathrm{CO}_{2}$ forcings. Paleoceanography 16(6), 574-590. DOI 10.1029/2000PA000579

Poulsen, C.J., Barron, E.J., Peterson, W.H. \& Wilson, P.A. 1999. A reinterpretation of mid-Cretaceous shallow marine temperatures through model-data comparison. Paleoceanography 14(6), 679-697. DOI 10.1029/1999PA900034

Poulsen, C.J., Seidov, D., Barron, E.J. \& Peterson, W.H. 1998. The impact of paleogeographic evolution on the surface oceanic circulation and the marine environment within the mid-Cretaceous Tethys. Paleoceanography 13(5), 546-559. DOI 10.1029/98PA01789

Price, G.D. \& HaRT, M.B. 2002. Isotopic evidence for Early to mid-Cretaceous ocean temperature variability. Marine Micropaleontology 46, 45-58. DOI 10.1016/S0377-8398(02)00043-9

RenARD, M. 1986. Pelagic carbonate chemostratigraphy (Sr, Mg, $\left.{ }^{18} \mathrm{O},{ }^{13} \mathrm{C}\right)$. Marine Micropaleontology 10, 117-164. DOI 10.1016/0377-8398(86)90027-7

Reuss, A.E. 1844. Die Kreidegebilde des westlichen Böhmens, ein monographischer Versuch. Geognostischen Skizzen aus Böhmen 2, 1-304. 
Ross, D.J. \& Skelton, P.W. 1993. Rudist formation of the Cretaceous: a paleoecological, sedimentological and stratigraphic review, 73-91. In WRIGHT, V.P. (ed.) Sedimentology review, vol. 1. Blackwell, London.

Saber, S., Salama, Y., Scott, R., Abdel-Gawad, G. \& Aly, M. 2009. Cenomanian-Turonian rudist assemblages and sequence stratigraphy on North Sinai carbonate shelf, Egypt. GeoArabia 14(2), 113-134.

Sageman, B.B., Meyers, S.R. \& Arthur, M.A. 2006. Orbital timescale and new $\mathrm{C}$-isotope record for Cenomanian-Turonian boundary stratotype. Geology 34, 125-128. DOI $10.1130 / \mathrm{G} 22074.1$

SAKaI, S. \& KANO, A. 2001. Original oxygen isotopic composition of planktic foraminifera preserved in diagenetically altered Pleistocene shallow-marine carbonates. Marine Geology 172(3-4), 197-204. DOI 10.1016/S0025-3227(00)00118-3

Shackleton, N.J. \& KenNetT, J.P. 1975. Paleotemperature history of the Cenozoic and the initiation of Antarctic glaciations: oxygen and carbon isotopic analyses in DSDP sites 277, 279 and 281, 743-755. In KenNET, J.P.\& Houtz, R.E. (eds) Initial reports of the Deep Sea Drilling Project (DSDP), Washington, 29.

Schafhauser, A., Götz, S., Baron-Szabo, R. \& Stinnesbeck, W. 2003. Depositional Environment of Coral-Rudist Associations inthe Upper Cretaceous Cardenas Formation (Central Mexico). Geologia Croatica 56(2), 187-198.

SHAHIN, A. 2007. Oxygen and carbon isotopes and foraminiferal biostratigraphy of the Cenomanian-Turonian succession in Gabal Nezzazat, southwestern Sinai, Egypt. Revue de Paléobiologie 26(2), 359-379.

Skelton, P.W. \& Wright, V.P. 1987. A Caribbean rudist bivalve in Oman - island-hopping across the Pacific in the Late Cretaceous. Palaeontology 30, 505-529.

Spero, H.J. \& LEA, D.W. 1996. Experimental determination of stable isotope variability in Globigerina bulloides: implications for paleoceanographic reconstruction. Marine Micropaleontology 28, 231-246.

DOI 10.1016/0377-8398(96)00003-5

StANLEY, S.M. 1995. New horizons for palaeontology, with two examples: The rise and fall of the Cretaceous Supertethys and the cause of the modern ice age. Journal of Paleontology 69, 999-1007.

Steuber, T. 1995. Stable isotope sclerochronology of Vaccinites cornuvaccinum (Hippuritidae) from Boeotia (Greece). Revista Mexicana de Ciencias Geológicas 12(2), 307-314.

Steuber, T. 1996. Stable isotope sclerochronology of rudist bivalves: growth rates and late Cretaceous seasonality. Geology 24, 315-318.

DOI 10.1130/0091-7613(1996)024<0315:SISORB >2.3.CO;2

STEUBER, T. 1999. Isotopic and chemical intra-shell variations in low-Mg calcite. International Journal of Earth Sciences 88, 551-570. DOI 10.1007/s005310050284

Steuber, T. 2002. Plate tectonic control on the evolution of Cretaceous platform-cabonate production. Geology 30(3), 259-262.

DOI 10.1130/0091-7613(2002)030<0259:PTCOTE >2.0.CO;2

Steuber, T. \& LÖSER, H. 2000. Species richness and abundance patterns of Tethyan Cretaceous rudist bivalves (Mollusca; Hippuritacea) in the central-eastern Mediterranean and Mid- dle East, analysed from a paleontological database. Palaeogeography, Paleoclimatology, Palaeoecology 162(1-2), 75-104. DOI 10.1016/S0031-0182(00)00106-1

Steuber, T., Rauch, M., Masse, J.-P., Graaf, J. \& Malkoč, M. 2005. Low-latitude seasonality of Cretaceous temperatures in warm and cold episodes. Nature 437(7063, October 27), 1341-1344.

Stoll, H.M. \& Schrag, D.P. 2000. High resolution stable isotope records from the Upper Cretaceous rocks of Italy and Spain: Glacial episodes in a greenhouse planet? Geological Society of America Bulletin 112, 308-319.

DOI 10.1130/0016-7606(2000)112<308:HSIRFT>2.0.CO;2

SvobodA, P. 1989. Korelace svrchnocenomanských marinních sedimentů mezi Kralupy nad Vltavou a Slaným. Bohemia centralis 18, 41-58.

Svoboda, P. 2006. Hercynian Cretaceous and the "plenus event". Acta Universitatis Carolinae 49, 169-180.

SwART, P.K. 1983. Carbon and oxygen isotope fractionation in scleractinian corals: a review. Earth Science Review 19, 51-80. DOI 10.1016/0012-8252(83)90076-4

Swart, P.K., Leader, J.J., Szmant, A.M. \& Dodge, R.E. 1996. The origin and variations in the isotopic record of scleractinian corals II. Geochimica et Cosmochimica Acta 60(15), 2871-2885. DOI 10.1016/0016-7037(96)00119-6

UličnÝ, D., Hladíková, J. \& Hradecká, L. 1993. Record of sea-level changes, oxygen depletion and the $\delta^{13} \mathrm{C}$ anomaly across the Cenomanian-Turonian boundary, Bohemian Cretaceous Basin. Cretaceous Research 14(2), 211-234. DOI 10.1006/cres.1993.1015

UličNÝ, D., KvaČEK, J., SvobodovÁ, M. \& ŠPIČÁKovÁ, L. 1997. High-frequency sea-level fluctuations and plant habitats in Cenomanian fluvial to estuarine sucession: Pecínov quarry, Bohemia. Palaeogeography, Palaeoclimatology, Palaeoecology 136, 165-197.

VoIGT, S. 1996. Paläobiogeographie oberkretazischer Inoceramen und Rudisten. Ozeanographische und klimatologische Konsequenzen einer neuen Palägeographie. Münchener Geowissenschaftliche Abhandlungen, Reihe A, Geologie und Paläontologie 31, 1-102.

Voigt, S. \& WiEse, F. 2000. Evidence for Late Cretaceous (Late Turonian) climate cooling from oxygen-isotope variations and palaeobiogeographic changes in Western and Central Europe. Journal of the Geological Society of London 157, 737-743. DOI 10.1144/jgs.157.4.737

Wagreich, M., Bojar, A.-V., SAChSEnhofer, R.F., Neuhuber, S. \& EGGER, H. 2008. Calcareous nannoplankton, planktonic foraminiferal, and carbonate carbon isotope stratigraphy of the Cenomanian-Turonian boundary section in the Ultrahelvetic Zone (Eastern Alps, Upper Austria). Cretaceous Research 29, 965-975. DOI 10.1016/j.cretres.2008.05.017

WEFER, G. \& BERGER, W.H. 1991. Isotope paleontology: growth and composition of extant calcareous species. Marine Geology 100, 207-248. DOI 10.1016/0025-3227(91)90234-U

WeISSERT, H. \& LinI, A. 1991. Ice Age includes during the time of Cretaceous greenhouse climate, 173-481. In MuelLeR, D.W., McKenzie, J.A. \& Weissert, H. (eds) Controversies in Modern Geology. Academic Pres, London.

Wiese, F., Čech, S., Ekrt, B., KoŠŤÁK, M., MAZuch, M. \& Voigt, S. 2004. The Upper Turonian of the Bohemian Cretaceous Ba- 
sin (Czech Republic) exemplified by the Úpohlavy working quarry: integrated stratigraphy and palaeoceanography of a gateway to the Tethys. Cretaceous Research 25(3), 329-352. DOI 10.1016/j.cretres.2004.01.003

Wiese, F. \& VoIGT, S. 2002. Late Turonian (Cretaceous) climate cooling in Europe: faunal response and possible causes. Geobios 35, 65-77. DOI 10.1016/S0016-6995(02)00010-4

Wiese, F., KošŤÁK, M. \& Wood, C.J. 2009. The Upper Cretaceous belemnite Praeactinocamax plenus (Blainville 1827) from Lower Saxony (Upper Cenomanian, Northwest Germany) and its distribution pattern in Europe. Paläontologische Zeitschrift 83(2), 309-321. DOI 10.1007/s12542-009-0022-8

WILSON, P.A. \& NoRRIS, R.D. 2001. Warm tropical ocean surface and global anoxia during the mid-Cretaceous period. Nature 412, 425-429. DOI 10.1038/35086553

Zachos, J.C., Stott, L.D. \& Lohmann, K.C. 1994. Evolution of Early Cenozoic marine temperature. Paleoceanography 9(2), 353-387. DOI 10.1029/93PA03266

ZIEGLER, V. 1982. Mineralogicko-petrografická a paleontologická charakteristika chráněného přírodního výtvoru Lom u Radimi (okres Kolín). Bohemia centralis 11, 17-28.

ZiEGLER, V. 1992. Stratigrafie a vrstevní sled křídových sedimentů v kolínské oblasti české křídové pánve. Časopis Národního muzea, Řada přirodovědná 160(1-4), 29-46.

Žítт, J. \& Nekvasilová, O. 1996. Epibionts, their hard-rock substrates, and phosphogenesis during the Cenomanian-Turonian boundary interval (Bohemian Cretaceous Basin, Czech Republic). Cretaceous Research 17, 715-739.

DOI 10.1006/cres.1996.0038

Žítt, J., Nekvasilová, O., Bosák, P., Svobodová, M., ŠTtemproKOVÁ-JírovÁ, D. \& ŠŤASTNÝ, M. 1997a. Rocky coast facies of the Cenomanian-Turonian Boundary interval at Velim (Bohemian Cretaceous Basin, Czech Republic). First Part. Bulletin of the Czech Geological Survey 72(1), 83-102.

Žítt, J., Nekvasilová, O., Bosák, P., Svobodová, M., ŠtemPROKOVÁ-JírovÁ, D. \& ŠŤASTNÝ, M. 1997b. Rocky coast facies of the Cenomanian-Turonian Boundary interval at Velim (Bohemian Cretaceous Basin, Czech Republic). Second Part. Bulletin of the Czech Geological Survey 72(2), 141-155.

Žítt, J., Kopéčová, M., Nekovařík, Č. \& PeZA, L.H. 1998. New data on the Late Cenomanian taphocoenose at Kuchyňka near Brázdim (Bohemian Cretaceous Basin). Journal of Czech Geological Society 47(1-2), 55-64. 